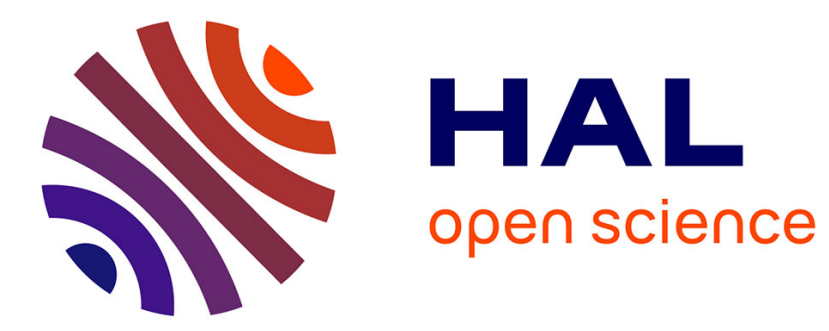

\title{
A pseudo-Lagrangian model study of the size distribution properties over Scandinavia: transport from Aspvreten to Värriö
}

P. Tunved, H. Korhonen, J. Ström, H.-C. Hansson, K. E. J. Lehtinen, M. Kulmala

\section{To cite this version:}

P. Tunved, H. Korhonen, J. Ström, H.-C. Hansson, K. E. J. Lehtinen, et al.. A pseudo-Lagrangian model study of the size distribution properties over Scandinavia: transport from Aspvreten to Värriö. Atmospheric Chemistry and Physics Discussions, 2004, 4 (6), pp.7757-7794. hal-00301514

\section{HAL Id: hal-00301514 https://hal.science/hal-00301514}

Submitted on 29 Nov 2004

HAL is a multi-disciplinary open access archive for the deposit and dissemination of scientific research documents, whether they are published or not. The documents may come from teaching and research institutions in France or abroad, or from public or private research centers.
L'archive ouverte pluridisciplinaire HAL, est destinée au dépôt et à la diffusion de documents scientifiques de niveau recherche, publiés ou non, émanant des établissements d'enseignement et de recherche français ou étrangers, des laboratoires publics ou privés. 


\section{A pseudo-Lagrangian model study of the size distribution properties over Scandinavia: transport from Aspvreten to Värriö}

P. Tunved $^{1}$, H. Korhonen ${ }^{2}$, J. Ström ${ }^{1}$, H.-C. Hansson ${ }^{1}$, K. E. J. Lehtinen ${ }^{3}$, and M. Kulmala ${ }^{3}$

${ }^{1}$ Institute for Applied Environmental Research, Stockholm University, SE-106 91, Stockholm, Sweden

${ }^{2}$ Finnish Meteorological Institute, POB 503, FIN-00101 Helsinki, Finland

${ }^{3}$ Department of Physical Sciences, University of Helsinki, POB 64, FIN-00014 Helsinki, Finland

Received: 16 August 2004 - Accepted: 4 October 2004 - Published: 29 November 2004 Correspondence to: P. Tunved (peter.tunved@itm.su.se)

(C) 2004 Author(s). This work is licensed under a Creative Commons License.

ACPD

4, 7757-7794, 2004

A pseudo-Lagrangian model study of the size distribution properties over Scandinavia

P. Tunved et al.

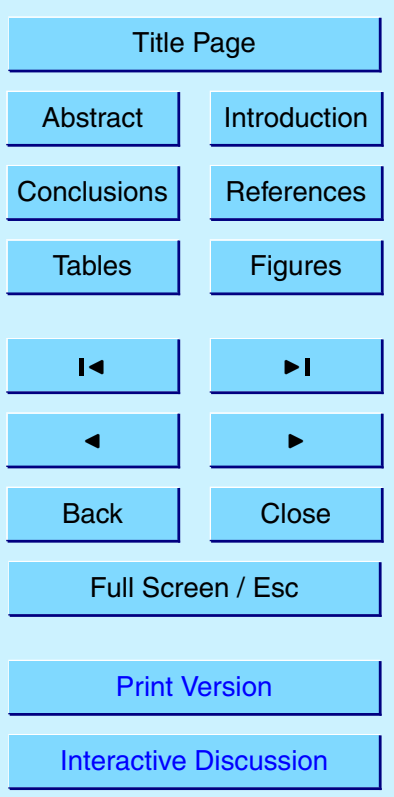




\section{Abstract}

The evolution of the aerosol size distribution during transport between Aspvreten $\left(58.8^{\circ} \mathrm{N}, 17.4^{\circ} \mathrm{E}\right)$ and Värriö $\left(67.46^{\circ} \mathrm{N}, 29.35^{\circ} \mathrm{E}\right)$ was studied using a pseudoLagrangian approach. Aerosol dynamic processes were studied and interpreted uti-

5 lizing a state-of-the-art aerosol dynamic box model UHMA (University of Helsinki Multicomponent Aerosol model) complemented with $\mathrm{OH}, \mathrm{NO}_{3}, \mathrm{O}_{3}$ and terpene chemistry. In the model simulations, the growth and formation of aerosol particles was controlled by sulphuric acid, ammonia, water and an unidentified low volatile organic compound. This organic compound was assumed to be a product of terpene oxidation with a yield of $13 \%$ in the base case conditions.

Changes of aerosol size distribution properties during transport between the stations were examined in twelve clear sky cases. On average, the modelled number agreed fairly well with observations. Mass concentration was overestimated by $10 \%$.

Apart from dilution, the only removal mechanism for aerosol mass is dry deposi15 tion. A series of sensitivity tests performed revealed that the absolute magnitude of dry deposition effects on the aerosol size distribution is slow overall. Furthermore, nucleation does not leave a significant contribution to aerosol number in the selected cases. The sensitivity of the modelled size distribution to concentration of precursor gases and oxidants is, however, obvious. In order to explain observed mass increase during transport we conclude that a yield of low volatile products from oxidation of terpenes of $10-15 \%$ is required to explain observed growth rates. Coagulation is acknowledged to be highly important in modelled cases.

\section{Introduction}

The atmospheric aerosol is believed to cool the climate through direct and indirect forcing. The direct forcing result from the ability of aerosols to scatter and absorb incoming solar radiation, while the indirect effect is a result of the ability of aerosols to
ACPD

4, 7757-7794, 2004

A pseudo-Lagrangian model study of the size distribution properties over Scandinavia

P. Tunved et al.

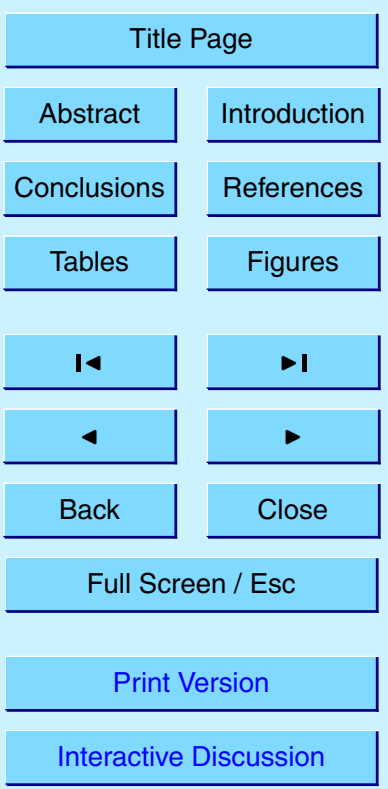


act as cloud condensation nuclei $(\mathrm{CCN})$ and thereby to alter the radiative properties of clouds (Twomey, 1974). An increased aerosol number concentration contributes to more cloud droplets and thus brighter clouds. Still, the climatic effects from particulate matter constitute the greatest uncertainty in climate models (IPCC, 2001).

5 Furthermore, aerosol particles are an important component of air pollution known to cause considerable public health effects. As the concentration of sulphur dioxide has decreased significantly in Europe during the recent decades attention is now turned to particulate matter. Epidemiological studies performed by e.g. Künzli et al. (2000) in three European countries attribute $6 \%$ of total mortality and a significant increase of 10 morbidity to air pollution.

On regional scale, the aerosol is associated with large temporal and spatial variability. In order to reduce the uncertainty associated with assumed effects of aerosols on climate we need to improve our understanding of the important dynamical processes controlling the aerosol size distribution on large spatial and temporal scales.

In order to perform studies of the importance of different source and sink processes affecting the aerosol it is favourable to make use of simultaneous measurements of aerosol properties on a regional scale. This type of measurement approach gives a relevant connection both in space and time, often lacking in previous investigations.

During recent years, regional long-term measurements of aerosol size distribution 20 have been evolving in the Nordic countries. So far, measurements from four stations in Finland and Sweden have resulted in a database comprising continuous and simultaneous aerosol size distribution and meteorological data since autumn 1999. Some of the stations contribute with longer records of size distribution measurements.

The stations in the existing Nordic measurement network are representative for the 25 background boreal environment, characteristic for Northern Europe (see Tunved et al., 2003 for a description of the network). The European boreal region covers more than $2900000 \mathrm{~km}^{2}$. Outside Europe, the type of ecosystem and climate characteristics encountered in this region find counterparts in especially north-western parts of USA and western Canada as well as parts of Northern Asia. Thus, the European boreal
ACPD

4, 7757-7794, 2004

A pseudo-Lagrangian model study of the size distribution properties over Scandinavia

P. Tunved et al.

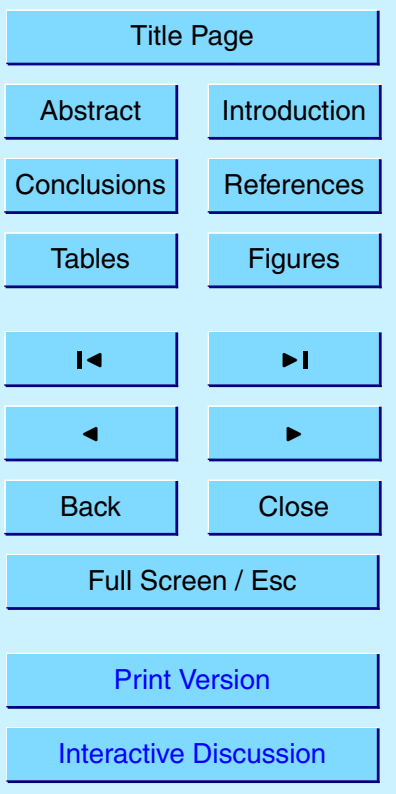


region is representative for economically important areas, including both sparsely and highly populated regions.

Recent investigation of the aerosol properties at these stations has mainly focused on the local properties of the aerosol and source-receptor relationships. Particularly 5 well studied is the role of nucleation in the boreal environment. Measurements performed at especially Hyytiälä have greatly improved our understanding of new particle formation in this type of environment (e.g. Mäkelä et al., 1997, 2000; Nilsson et al., 2001a, b; Kulmala et al., 1998, 2001, 2004a).

From previous investigations of changes of aerosol size distribution properties dur10 ing transport in-between the stations in the network several features was exposed. Firstly, the processes acting on the aerosol over the time scale of transport between the stations are rapid. This further implies that constant aerosol fields may not be used to characterize the aerosol over scales defined by Northern Europe (Tunved et al., 2003). Tunved et al. (2003) concluded that during southerly transport the air masses experience a source of aerosol number, while transport from south to north often is associated with a significant decrease in aerosol number and mass concentration. The increase of aerosols during southerly transport is likely to be explained by gas to particle formation. Nucleation is often observed in air-masses arriving from north, probably due to low pre-existing aerosol surface and typical mixing and temperature profiles in this kind of air-masses (Nilsson et al., 2001a, b).

In the present study we utilize a box model approach to explore the role of different processes shaping the aerosol during transport under clear sky conditions. The investigation is limited to studying the transport from south to north making use of two background stations as reference points for our model study (Aspvreten, some $70 \mathrm{~km}$ 25 south of Stockholm $\left(58.8^{\circ} \mathrm{N}, 17.4^{\circ} \mathrm{E}\right)$ and Värriö, Finnish Lapland $\left(67.46^{\circ} \mathrm{N}, 29.35^{\circ} \mathrm{E}\right)$ ). We utilize a pseudo-Lagrangian box model approach to explain the observed decrease in particle mass and number concentration and to explore the role of different processes in shaping the aerosol population under clear sky conditions. Twelve different transport situations were modelled and compared to observations. Sensitivity tests
ACPD

4, 7757-7794, 2004

A pseudo-Lagrangian model study of the size distribution properties over Scandinavia

P. Tunved et al.

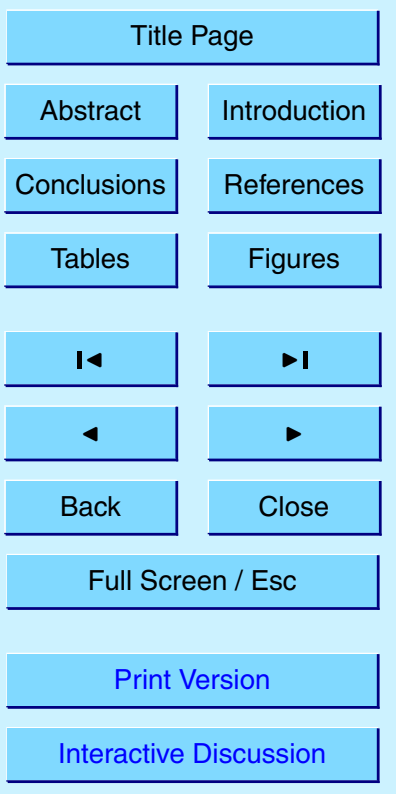


are performed for one selected case in order to address the importance of different dynamical processes affecting the aerosol.

\section{Methods}

\subsection{Stations and size distribution measurements}

5 Simultaneous size distribution measurements from two stations during a period of one year (1 June 2000 to 31 May 2001) are utilized in this study. Both stations utilized similar observational methods by means of Differential Mobility Particle Sizer (DMPS).

The SMEAR I station $\left(67.46^{\circ} \mathrm{N} 29.35^{\circ} \mathrm{E}, 400 \mathrm{~m}\right.$ a.s.I.) in Värriö is located in Finnish Lapland. The station is far from any pollution sources. However, emissions on the 10 Kola Peninsula give rather strong signals (especially high $\mathrm{SO}_{2}$ and particle number and mass) when winds are transporting air from this region (e.g. Kulmala et al., 2000). The Differential Mobility Particle Sizer (DMPS) system set-up observes a complete size scan between 8 and $460 \mathrm{~nm}$ approximately every $10 \mathrm{~min}$.

Aspvreten $\left(58.80^{\circ} \mathrm{N}, 17.40^{\circ} \mathrm{E}, 25 \mathrm{~m}\right.$ a.s.I.), is located in the county of Sörmland, 15 some $70 \mathrm{~km}$ south west of Stockholm. The station is situated $2 \mathrm{~km}$ inland from the Baltic Sea. Influence from local anthropogenic activities is minimal (Tunved et al., 2003). The DMPS instrument set-up observes one size distribution spectrum every $6 \mathrm{~min}$ in the size ranges $10-452 \mathrm{~nm}$.

\subsection{Pseudo-Lagrangian assumption}

20 In this work, we investigated the importance of different dynamic and chemical processes affecting the aerosol during transport from south to north with the help of a pseudo-Lagrangian approach. A detailed aerosol dynamics model was run along trajectories passing through both a southern source region defined by Aspvreten and the northern receptor region characterised by Värriö. The continuous particle size distribu-
ACPD

4, 7757-7794, 2004

A pseudo-Lagrangian model study of the size distribution properties over Scandinavia

P. Tunved et al.

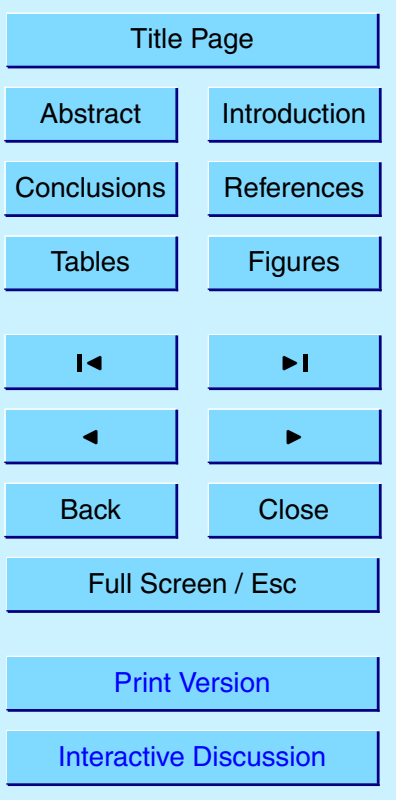


tion measurements at both stations enable us to test our understanding of the factors shaping the size distribution during the transport.

The $120 \mathrm{~h}$ trajectories with one-hour resolution were calculated with the HYSPLIT4 model (Draxler and Hess, 1997, 2003). The trajectory calculation relies on 5 NCEP/GDAS FNL reanalysis data. The trajectory gives transport time and the time dependent meteorological output data for each of the endpoints. This allows us to run the aerosol dynamic model along each trajectory with adequate meteorological input.

Trajectories are calculated arriving to the receptor site $10 \mathrm{~m}$ a.g.l. Trajectories where used only if spending a majority of time in the boundary layer.

\subsection{Aerosol dynamic model}

The aerosol dynamic box model run along the trajectories was the University of Helsinki Multicomponent Aerosol model (UHMA) described in detail in Korhonen et al. (2004). The model incorporates the major microphysical processes that affect the aerosol under clear sky conditions, namely nucleation, coagulation, multicomponent condensa5 tion and dry deposition.

In this study, the vapours condensing onto aerosol particles were sulphuric acid, ammonia, water and a low-volatile organic compound following the nano-Köhler mechanism, suggested by Kulmala et al. (2004b), and thus capable of contributing to the growth of newly formed particles after a threshold size of few nanometres was reached. sphere, analysis of new particle formation events in boreal forest have shown that sulphuric acid can explain only a small fraction of the observed growth of nucleation mode particles (Boy et al., 2003). Furthermore, indirect experimental evidence indicates that the dominant compounds contributing to the growth of newly formed particles in forested areas are organic (O'Dowd et al., 2002).

The dry deposition rate of particles was calculated according to Rannik et al. (2003) over land and according to Slinn et al. (1978) over sea. Nucleation was simulated according to the kinetically limited nucleation mechanism, which essentially gives the
ACPD

4, 7757-7794, 2004

A pseudo-Lagrangian model study of the size distribution properties over Scandinavia

P. Tunved et al.

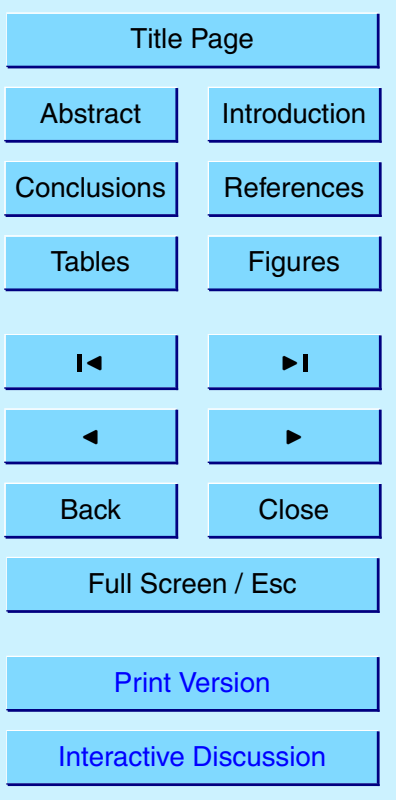


maximum nucleation rate under prevailing conditions. While the details of the atmospheric nucleation mechanism in the boundary layer are not known, Laakso et al. (2004) have shown that observed particle formation events in the boreal site Hyytiälä are more likely limited by gas-phase kinetics than thermodynamics.

5 The particle size distribution was approximated with 55 size sections in the size range of $0.7 \mathrm{~nm}-2 \mu \mathrm{m}$. Of the three size distribution descriptions available in UHMA, this study utilized the hybrid structure. In this structure, the particles are split into fixed size sections based on their core volume of sulphuric acid and condensable organic matter. The advantage with the approach is that it eliminates the numerical diffusion 10 associated with the condensation of ammonia and water, the amount of which in the particle phase is determined by equilibration at every model time step.

\subsection{Treatment of chemistry}

In the model we assume two species, except water vapour and ammonia, to control the growth and formation of particles: sulphuric acid, which is formed by oxidation 15 of $\mathrm{SO}_{2}$ by hydroxyl radical $(\mathrm{OH})$ and some unidentified product from degradation of terpenes formed by reaction between terpenes and hydroxyl radical $(\mathrm{OH})$, ozone $\left(\mathrm{O}_{3}\right)$ and nitrate radical $\left(\mathrm{NO}_{3}\right)$. Concentration of $\mathrm{OH}$ and $\mathrm{NO}_{3}$ is calculated assuming steady state following Janson et al. (2001).

Concentration of $\mathrm{OH}$ is determined by assuming balance between formation and 20 degradation of $\mathrm{HO}_{\mathrm{x}}\left(\mathrm{OH}, \mathrm{HO}_{2}\right)$. Sources of $\mathrm{HO}_{\mathrm{x}}$ are reaction of singlet oxygen $\left(\mathrm{O}^{1} \mathrm{D}\right)$, produced from photolysis of $\mathrm{O}_{3}$, and water vapour. Photolysis of $\mathrm{HCHO}$ and ozonlysis of terpenes also contributes to $\mathrm{OH}$ production. Photolysis constants are taken from Derwent and Jenkin (1990). Clear sky conditions are assumed. Solar zenith angles are calculated along trajectories from geographical coordinates, day of year and time of day. The sinks of odd oxygen are $\mathrm{HO}_{2}-\mathrm{HO}_{2}$ self-reaction, reaction with terpenes, $\mathrm{OH}-\mathrm{HO}_{2}$ reaction and formation of nitric acid from combination of $\mathrm{OH}$ and $\mathrm{NO}_{2}$. Daily average of calculated $\mathrm{OH}$ concentration was adjusted to be of same magnitude as reported by Hakola et al. (2003) using an observationally constrained box model. Slightly

ACPD

4, 7757-7794, 2004

A pseudo-Lagrangian model study of the size distribution properties over Scandinavia

P. Tunved et al.

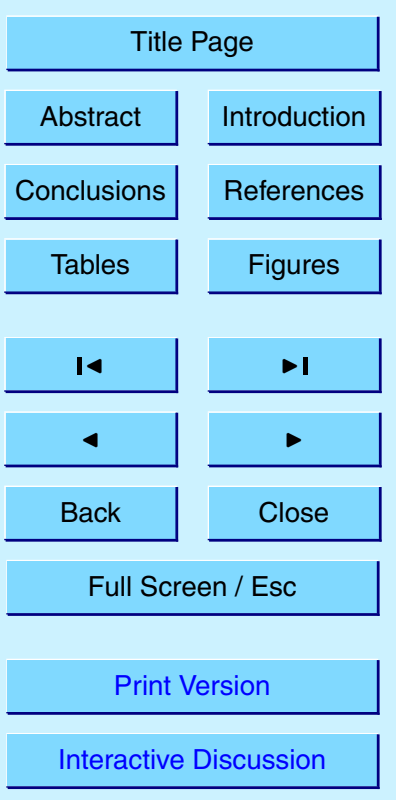


higher values were however used in the present study.

Nitrate radical is formed by reaction of $\mathrm{NO}_{2}$ and $\mathrm{O}_{3} . \mathrm{NO}_{3}$ is highly sensitive to photolytic degradation and reaches near zero concentration during daytime. Temperature dependent dissociation and photolysis of $\mathrm{N}_{2} \mathrm{O}_{5}$ also serves as source of nitrate radical.

$5 \mathrm{NO}_{3}$ is consumed due to photolysis, $\mathrm{NO}_{3}-\mathrm{NO}$ reaction, $\mathrm{NO}_{3}-\mathrm{NO}_{2}$ reaction and reaction of $\mathrm{NO}_{3}$ with terpenes.

To account for terpene emissions a parameterisation of this process, as presented by Lindfors et al. (1999) was implemented. The approach includes temperature dependent emissions of terpenes in grams per gram dry weight foliar biomass. Terpene 10 emissions are exponentially dependent on temperature. The parameterisation relies on a latitude dependent biomass density which is valid for Finland over latitudes from $60^{\circ} \mathrm{N}$ to $69^{\circ} \mathrm{N}$. As the Swedish source site investigated lies on lower latitude, we extrapolated the data behind the parameterization for latitudes down to 58.8. Furthermore, we assumed that the parameterisation is also representative of Swedish forested ar15 eas.

Once emitted, mono-terpenes are subjected to degradation by ozone, hydroxyl radical and nitrate radical. The rate constants for initial chemical reactions are rather well known for the most commonly encountered terpenes. We do not discriminate between different terpene species. Average rate constants for primary oxidation steps for the dominating terpene species (Janson et al., 2001) were used. Average molar mass of oxidation products is set to $150 \mathrm{~g} / \mathrm{mol}$.

\subsection{Data usage and design of base case}

Some 60 trajectories describe transport between Aspvreten and Värriö during the period of investigation. This investigation focuses on transport during clear sky conditions

only. By investigating satellite images and relative humidity $(\mathrm{RH})$ history of the single trajectories we are rather certain that at least 20 of the selected trajectories actually describe transport without influence of clouds or precipitation.

However, further precautions need to be included in this analysis. One of the main 7764
ACPD

4, 7757-7794, 2004

A pseudo-Lagrangian model study of the size distribution properties over Scandinavia

P. Tunved et al.

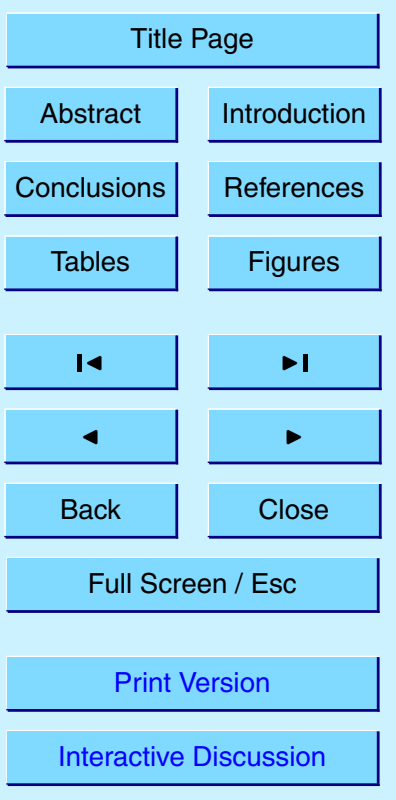


concerns is the selection of an input aerosol at Aspvreten. Since the observed aerosol properties are dependent on source area we need to make certain that the conditions do not change significantly during a period of at least $6 \mathrm{~h}$ when the trajectory crosses Aspvreten. We only accept cases where small variability of aerosol number in the 5 Aitken and accumulation mode size ranges is present during a $6 \mathrm{~h}$ period. This means that the aerosol reaching Aspvreten during this period of time is uniform and the influence from local sources is small. It is also necessary to assure that the advection is stable throughout at least $6 \mathrm{~h}$ by investigating the grouping of subsequent trajectories. Figure 1 displays a typical case which fulfils the homogeneity criterion for the size distri10 bution. The $6 \mathrm{~h}$ median size distribution and the quartile ranges observed at Aspvreten on 29 August 2000 at the time when the trajectory passed the site are shown.

Figure 2 illustrates typical transport situations during our selected cases. 4 trajectories are calculated with some $100 \mathrm{~km}$ around the arrival point, defining a square around the receptor station. The trajectory arriving Värriö is indicated in the middle of 15 this square. Three levels are considered, 10, 100 and $200 \mathrm{~m}$, to assure a stable boundary layer transport. The picture reveals a stable flow from Aspvreten to Värriö. Due to vertical wind-shear a westward shift in trajectory orientation is observed. This shift is however small. By further investigating the flow situation at $\pm 3 \mathrm{~h}$ around the selected transport occasions we assure that no significant changes in transport pattern occur over the period of sampling at the receptor station.

In the base case of the model calculations we use input of gases as given in Table 1. Sulfur dioxide, ozone and nitrogen oxides are estimated as the monthly average concentration of these species during southerly winds as observed at Hyytiälä (data from Hyytiälä, 2001-2003). Hyytiälä is located in the middle of Finland. Since no measurements of gases except ozone is performed at Aspvreten we have to rely on observations from Hyytiälä, assumed to be somewhat representative for gas concentrations observed at Aspvreten. $\mathrm{NO}_{\mathrm{x}}$ is partitioned between $\mathrm{NO}_{2}$ and $\mathrm{NO}$ following typically observed diurnal variation. $\mathrm{SO}_{2}, \mathrm{NO}_{\mathrm{x}}, \mathrm{O}_{3}, \mathrm{NH}_{3}, \mathrm{HCHO}, \mathrm{CH}_{4}$ and $\mathrm{CO}$ is assumed constant during the model runs. $\mathrm{HCHO}, \mathrm{CH}_{4}$ and $\mathrm{CO}$ are taken from Janson
ACPD

4, 7757-7794, 2004

A pseudo-Lagrangian model study of the size distribution properties over Scandinavia

P. Tunved et al.

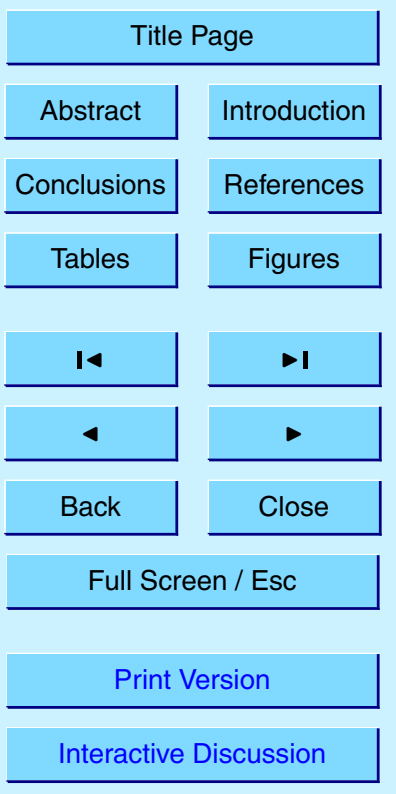


et al. (2001). Water vapour is estimated from relative humidity and temperature along the trajectory. Meteorological input such as temperature, pressure and boundary layer height was taken from trajectory model.

Terpenes are emitted from vegetation according to parameterisation in Sect. 2.4 and 5 a yield of condensable products of 0.13 was assumed in the base case. In the base case only chemistry including the major oxidants $\mathrm{OH}, \mathrm{O}_{3}$ and $\mathrm{NO}_{3}$ is considered. We do not know the actual vapour pressure of the wide range of possible products from terpene oxidation. The saturation vapour pressure over flat surface for the condensable species is therefore approximated to be $3 \times 10^{6}$ (molecules $\left.\times \mathrm{cm}^{-3}\right)$. According to 10 Kulmala et al. (1998) similarly low vapour pressure is required to explain the observed growth of freshly formed nano-particles.

In the base case a two-layer structure of the lowermost troposphere was assumed. The lower layer was defined by the boundary layer height as given by the trajectory model. Above this layer a residual layer was assumed to exist. For simplicity, this residual layer height is constant at $2000 \mathrm{~m}$ and defines a volume given by the difference in mixing layer height and the upper limit of the residual layer. This approach is reasonable. When the temperature profile alters and boundary layer height decrease parts of the aerosol will be left in this residual layer. Since the mixing in the lowermost free troposphere only is slow, it is rather safe to assume that the aerosol is confined within the residual layer at least during the time scale of days. This residual layer serves as a second reservoir of aerosols. The aerosol will partly be fumigated back in the mixing layer once the mixing layer height increase again. Within the residual layer, the aerosol is only affected by coagulation nucleation and condensation. The air in the mixing layer is in direct connection with sources of organic compounds, and also 25 subjected to dry deposition. The air in the residual layer only get supply of condensable organic vapours and precursors thereof via vertical pumping associated with the diurnal variation in boundary layer height. This means that the growth of the nucleated particles in the residual layer will be slower as compared with mixing layer and further. This treatment naturally is associated with some portion of uncertainty, but as we will
ACPD

4, 7757-7794, 2004

A pseudo-Lagrangian model study of the size distribution properties over Scandinavia

P. Tunved et al.

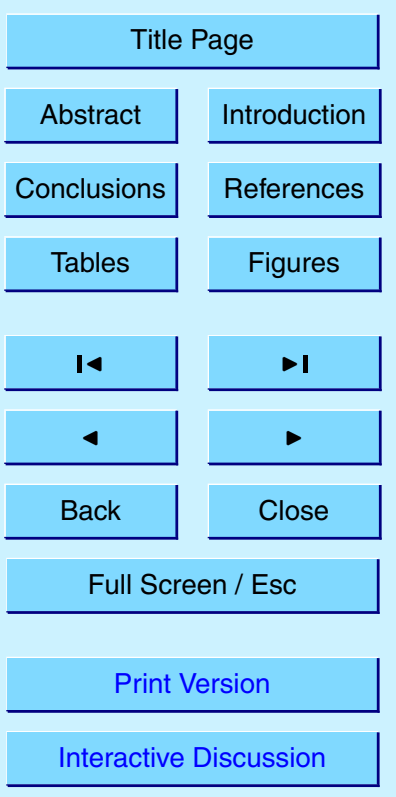


see much more realistic than assuming e.g. mixing with zero air or attempting to define an aerosol in the free troposphere where measurements for the location currently not are available. The approach neglects any entrainment from the free troposphere.

\section{Results}

\section{3.1. General size distribution properties}

Of the 60 trajectories describing transport between Aspvreten and Värriö, only 12 fulfilled the strict criteria stated in Sect. 2.5. The major branch of trajectories describes transport from a sector NE-SE, over the Baltic states before crossing the area around Aspvreten and from there transport occurs following a somewhat straight line up to

10 Värriö. 4 of the selected trajectories initially describe transport from NW, but the air parcels changes direction in southern Sweden and is subsequently transported north over Aspvreten up to Värriö.

The transport time between Aspvreten and Värriö in the selected cases vary between 50 and $120 \mathrm{~h}$ with an average transport time of $85 \mathrm{~h}$ ( $\sim 3.5$ days). Data from size distribution measurements at both stations is presented in Fig. 3. Quartile ranges and median distribution for the receptor Värriö and the source station Aspvreten are depicted. At Aspvreten the number concentration is on average $2400 \mathrm{~cm}^{-3}$. Corresponding average mass concentration, assuming a density of $1.5 \mathrm{~g} / \mathrm{cm}^{3}$, observed at Aspvreten is $3.1 \mu \mathrm{g} / \mathrm{m}^{3}$. The air observed at Värriö after transport contains a substantial lower number concentration, on average $1500 \mathrm{~cm}^{-3}$. Average integrated mass concentration observed at Värriö was $4.1 \mu \mathrm{g} / \mathrm{m}^{3}$. Increase in mass is observed in $60 \%$ of the cases. Significant number decrease is observed in most cases. In those cases where number increase is observed, this increase is typically small.

\section{ACPD}

4, 7757-7794, 2004

A pseudo-Lagrangian model study of the size distribution properties over Scandinavia

P. Tunved et al.

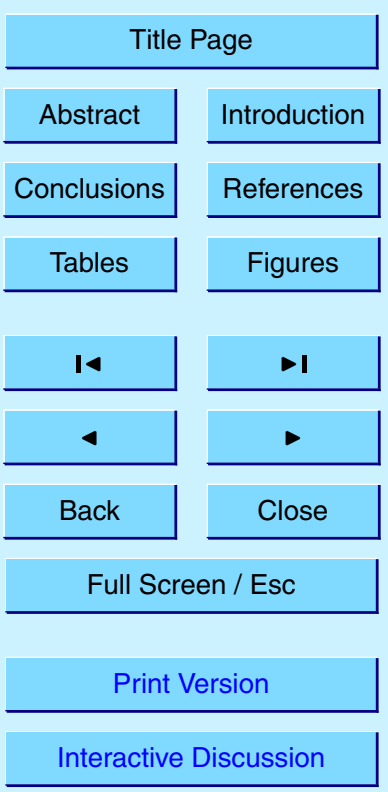


In the ten selected cases, we ran the aerosol dynamic model UHMA along the trajectories using the 6-hour median size distribution measured at Aspvreten as an input. Since no measurements of the particle composition are available, the initial ratio of sul-

5 phate and soluble organics in nucleation, Aitken and accumulation modes is assumed to be $7: 3,1: 1$, and $3: 2$, respectively.

The bulk concentration of assumed low volatility terpene oxidation products in these runs are on average (over land) $1.67 \times 10^{7}$ (molecules $\times \mathrm{cm}^{-3}$ ). Corresponding concentration of terpene precursors over land was on average $4.3 \times 10^{9}\left(\right.$ molecules $\left.\times \mathrm{cm}^{-3}\right)$.

10 Assuming standard conditions, this corresponds to a terpene mixing ratio of $150 \mathrm{pptv}$ on average. Source rate of condensable products from terpene oxidation by $\mathrm{OH}, \mathrm{O}_{3}$ and $\mathrm{NO}_{3}$ is on average $6.5 \times 10^{4}$ (molecules $\times \mathrm{cm}^{-3}$ ). No discrimination between saturation vapour pressures of different products is done. Considering that the modelled cases are confined to summer and comparing with observed terpene concentrations at different heights in Hyytiälä August 1999 (Janson et al., 2001) and spring 1998-1999 (Spanke et al., 2001) the modelled concentrations are well in agreement with measurements. Daytime reaction of terpenes and $\mathrm{SO}_{2}$ are dominated by reactions with $\mathrm{OH}$. The diurnal variability of $\mathrm{OH}$ is governed by fluctuations in water vapour and solar zenith angle (sza). Maximum of $\mathrm{OH}$ is predicted during noon. Daily maximum $\mathrm{OH}$ concentration 20 was typically estimated to be $2-8 \times 10^{6} \mathrm{~cm}^{-3}$. Daily maximum of $\mathrm{H}_{2} \mathrm{SO}_{4}$ was typically $1-3 \times 10^{6} \mathrm{~cm}^{-3}$, with variations governed by latitude and water vapour concentration, pre-existing aerosol concentration and input concentration of $\mathrm{O}_{3}, \mathrm{SO}_{2}$ and $\mathrm{NO}_{\mathrm{x}}$.

In Fig. 4 four different cases from the model run is shown. In some cases the model result is completely in agreement with observations as in case A (upper frame Fig. 4).

25 The accumulation mode concentration is slightly underestimated for particles of size $>250 \mathrm{~nm}$, but the model manages to accurately capture the characteristic features of both nuclei mode and Aitken mode size range. The deficiency of simulated number concentration above $250 \mathrm{~nm}$ compared with observations might be result of primary

\section{A pseudo-Lagrangian model study of the size distribution properties over Scandinavia}

P. Tunved et al.

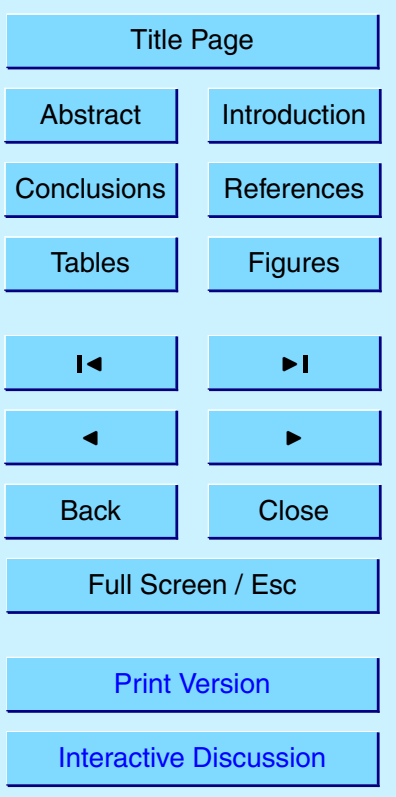


emissions, unaccounted for by the model. In this case the evolution of the size distribution is characterised by significant growth of the initial Aitken mode. Recalling no primary sources are included in the model, it is obvious that growth by condensation is capable of moving Aitken mode particles up to accumulation mode size range over a 5 time period of a few days. Further, it is obvious that even if nucleation does not result in an overall number increase, addition of freshly formed particles is necessary in order to capture observed features.

This is also evident in case $B$. The modelled size distribution excellently represents the observed aerosol size distribution for both Aitken and nuclei mode particles, but 10 fails in reproducing the observed accumulation mode. This might indicate an underestimated growth rate in the model or possible primary emissions.

On the other hand, case $C$ excellently captures the accumulation mode concentration, but in doing so the nuclei mode and particles in the lower Aitken mode size range is underestimated. This indicate that the modelled nucleation and subsequent growth 15 is too slow compared with observations, leading to the predicted particle depletion in the sub $50 \mathrm{~nm}$ size range.

In Case $D$ the accumulation mode is clearly overestimated, leading to significant mass-increase during transport. In this case it is obvious that the condensation growth is overestimated. Also number representation by the model in nuclei and Aitken size 20 range is poor.

Average model output is depicted in Fig. 5. Median and quartile ranges for Värriö observational size distribution data and modelled results for the 12 selected cases are displayed. The location of the Aitken mode is on average excellently captured by the model. The number concentration is slightly underestimated for smaller size aerosols mated on average by $10 \%$ and the mass concentration is overestimated $10 \%$ on average. The good agreement between average properties of simulated and observed aerosol size distribution indicate that the representation and balance between different dynamical processes is fairly good.

ACPD

4, 7757-7794, 2004

A pseudo-Lagrangian model study of the size distribution properties over Scandinavia

P. Tunved et al.

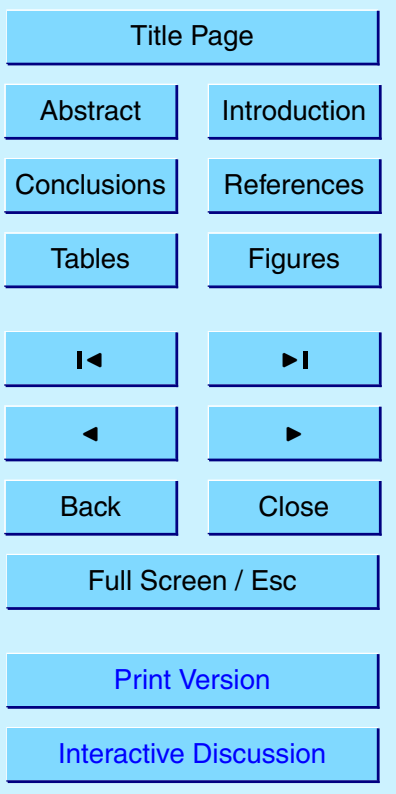


When investigating single cases, however, it is found that although the model overestimates the mass in most cases, it is underestimated in a few cases. General statistics for the measured and modelled particles in the size range $10-450 \mathrm{~nm}$ are shown in Table 2. The four selected case clearly indicate the weaknesses associated with the 5 model. The shortcomings are mainly the result of failure in reproducing concentration of condensable species, as is clearly indicated by miscalculated growth rates. In order to better understand the models response to changes of different parameters the following part of the investigation is dedicated to sensitivity analysis.

\subsection{Sensitivity tests}

10 In the following we focus on a single transport case to perform a more detailed investigation of the importance of different dynamical processes controlling the evolution of the size distribution. As reference we use an air-parcel arriving Värriö on 29 August 2000 at 05:00 UTC. The transport time is $77 \mathrm{~h}$. The transport pattern for this case is depicted for three arrival heights in Fig. 2, Sect. 3.1.

15 Size distribution data for Värriö $t=0$ and Aspvreten $t=-77 \mathrm{~h}$ is shown in Fig. 6 . The size distribution observed at Värriö is dominated by accumulation mode particles. The size distribution observed at Aspvreten $77 \mathrm{~h}$ earlier contains large amount of Aitken mode particles. A significant shift in size distribution occurs during transport.

In Fig. 7, the modelled time evolution of the aerosol size distribution under base case conditions is shown. Initially the air is transported over the Baltic Sea. Therefore, it is not affected by emissions from underlying vegetation. During this time, there are indications of new particle formation. However, the growth is too slow to significantly alter the number of particles larger than $10 \mathrm{~nm}$. As the air reaches the Finnish coast after $48 \mathrm{~h}$, emissions of terpenes begin to influence the air mass. Over the sea, the lack of organics limited the growth of the freshly formed particles. As the air is exposed to the source of terpenes, an increased growth rate is observed. The organics are able to shift some of the particles up to around $20-30 \mathrm{~nm}$ before these particles are scavenged by coagulation. During the last day of the simulation a new nucleation is initialised.
ACPD

4, 7757-7794, 2004

A pseudo-Lagrangian model study of the size distribution properties over Scandinavia

P. Tunved et al.

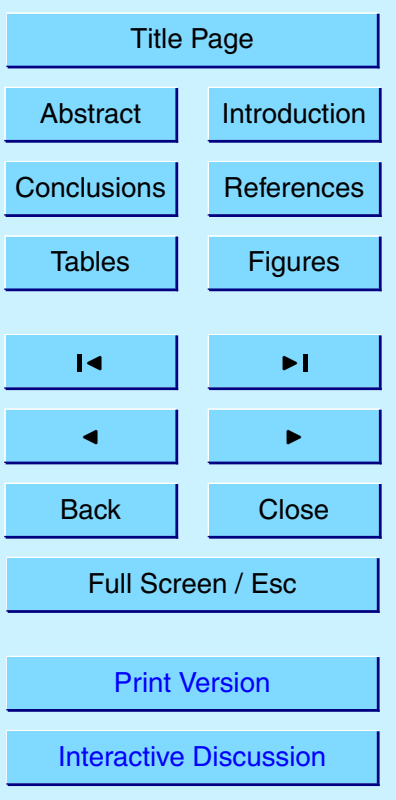


In the presence of low volatile organic products, the nucleated aerosol grows rather rapidly. The concentration of pre-existing aerosols is however large, and the growth rate is not sufficiently rapid to move the freshly formed particles into sizes where they will remain as individual particles. The model predicts contributions of particles larger 5 than $10 \mathrm{~nm}$ at the end of the run as indicated in Case A (Fig. 4) However, due to the strong sinks present, nucleation only contributes with a small fraction to the total particle number as the air reaches Värriö.

Comparison of the modelled time evolution with time series of aerosol size distribution observations performed at Värriö before and after the arrival of the trajectories is 10 shown in Fig. 8. There is no sign of well defined nucleation as described by Mäkelä et al. (2000) going on during either of the days. However, contributions of small particles are noticed sporadically. Especially, a peak in sub-20 nm particles appears in the afternoon on 29 August. Contribution of small particles is also noticed during morning hours on 29 August. Considering the time scale of removal for such small aerosols, these particles are likely to have been formed recently. This means that the model is in agreement with observations. Even if no pronounced nucleation event is indicated in observations, new particle formation obviously occur close to the receptor site.

Using this day as a reference, a number of different tests were performed in order to examine the processes determining the size distribution dynamics and to test the sensitivity of the model. The selected runs are summarized in Table 3. All these cases should be compared to the modelled base case. In the base case run, the mass concentration is $3.7 \mu \mathrm{g} \times \mathrm{m}^{-3}$ and the integrated number concentration is $1980 \mathrm{~cm}^{-3}$. Figure 9 provides a graphical summary of the modelled cases explained in detail below.

\subsubsection{Case 1: Dependence on $\mathrm{OH} / \mathrm{SO}_{2}$ concentration}

25 In order to determine the role of photochemical reaction, we tested the model sensitivity to an increased concentration of $\mathrm{OH}$ radicals. The source term of $\mathrm{OH}$ was increased an order of magnitude. Under these selected conditions, $\mathrm{OH}$ concentration reached daily maximum of $5 \times 10^{7}$. This significantly increases the concentrations
ACPD

4, 7757-7794, 2004

A pseudo-Lagrangian model study of the size distribution properties over Scandinavia

P. Tunved et al.

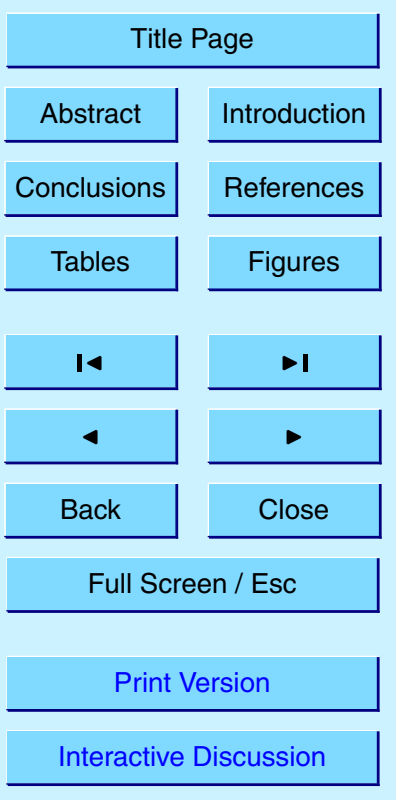


of both sulphuric acid and especially daily concentration of condensable organic oxidation products. The higher condensable vapour concentrations naturally lead to an increased growth rate of the particles but also to an increased nucleation rate. These changes have dramatic effects on the resulting size distribution: both number and mass 5 increase significantly. The resulting size distribution bears no similarities with the observational data or modelled base case conditions (see Fig. 9, upper frame) due to the major increase in nucleation rate. The resulting number concentration in this case is predicted to $5000 \mathrm{~cm}^{-3}$ compared with observed integral concentration of $1400 \mathrm{~cm}^{-3}$. The ternary $\left(\mathrm{H}_{2} \mathrm{O}-\mathrm{H}_{2} \mathrm{SO}_{4}-\mathrm{NH}_{3}\right)$ nucleation mechanism used in this model is nonlinear, 10 and even small changes in the input concentration can give rise to large responses in nucleation rate. Similar test was done to $\mathrm{SO}_{2}$ concentration whose concentration was increased tenfold (corresponding to $1.4 \mathrm{ppb}$ in this particular case). This gave results similar as ten-fold increase of $\mathrm{OH}$ concentration.

\subsubsection{Case 2: Dependence condensable product yield from terpene oxidation}

15 The yield of condensable products from terpenes is crucially important for an accurate description of the growth of both pre-existing and recently formed particles. It is generally assumed that some additional condensable species besides sulphuric acid is required to explain the growth rate observed in Eularian experiments such as performed at Hyytiälä (e.g. Kulmala et al., 2001). Low volatile products from terpene oxidation are 20 often argued to be possible contributors to the observed growth rate (e.g. Janson et al., 2001). In the base case we used a yield $13 \%$. This is in agreement with estimates from Leaitch et al. (1999) (Canadian boreal forest) who estimated the aerosol mass yield from terpene oxidation to be at least $13 \%$.

Since the terpene aerosol yield is highly uncertain it is necessary to investigate how 25 the system responds to changes thereof. Two cases were selected varying the yield over almost an order of magnitude: one case in which the yield was assumed to be $3 \%$ based on the formation on low volatile di-acids from terpene oxidations (Boy et al., 2003 and references therein) and one with a major increase in aerosol yield (25\%). In
ACPD

4, 7757-7794, 2004

A pseudo-Lagrangian model study of the size distribution properties over Scandinavia

P. Tunved et al.

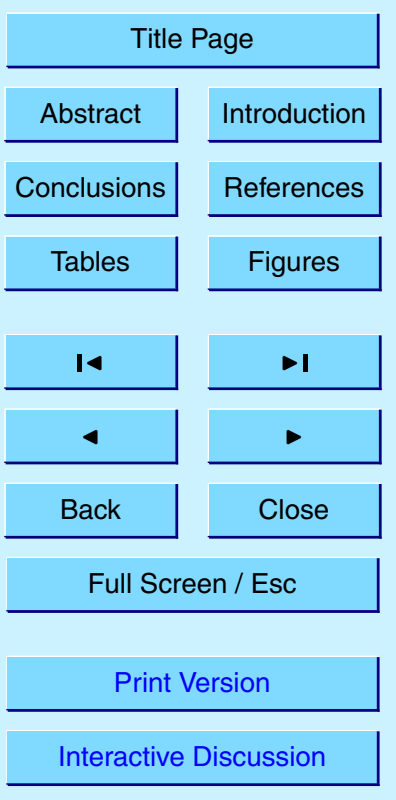


the case of lowering the yield to 0.03 the resulting mass at Värriö would be $1.7 \mu \mathrm{g} \times \mathrm{m}^{-3}$.

The mass at Aspvreten ( $t=-76 \mathrm{~h}$ ) was integrated between $10-450 \mathrm{~nm}$ and corresponds to $1.9 \mu \mathrm{g} \times \mathrm{m}^{-3}$. The modelled increase in mass value should be compared with the observed value $6.0 \mu \mathrm{g} \times \mathrm{m}^{-3}$ (assuming $\rho=1.5 \mathrm{~g} / \mathrm{cm}^{3}$ ). It is therefore determined that

5 if terpenes are responsible for the observed mass, the yield of condensing species must be higher than 0.03 . As discussed by Boy et al. (2003) di-acids are necessary to explain the growth of thermodynamically stable clusters but larger saturation vapour pressures may support the growth of larger particles.

Applying the yield of 0.25 gives a resulting mass at Värriö of $6.5 \mu \mathrm{g} / \mathrm{m}^{3}$. The result10 ing size distribution is associated with higher number concentration in both Aitken and accumulation mode, obviously different from observational data. The test clearly displays the sensitivity of the model to the estimated aerosol yield. Base case conditions capture the appearance of the observed size distribution fairly well. Assuming correct representation of terpene emissions and accurate estimates of concentration of major oxidants it is therefore likely that yield of condensable products from terpene oxidation is close to $10-15 \%$.

\subsubsection{Case 3: Role of dry deposition}

In an idealised case, deposition and dilution are the only processes capable of lowering the mass concentration of aerosols in the absence of wet deposition. This means that an accurate description of deposition is required to capture the aerosol properties during transport under clear sky conditions. In order to investigate the sensitivity to dry deposition we tested the model performance by shutting off deposition completely. As a result, the modelled mass at Värriö increased to $4 \mu \mathrm{g} / \mathrm{m}^{3}$, compared to $3.7 \mu \mathrm{g} / \mathrm{m}^{3}$ in the base case. Beside the small increase in mass achieved when shutting of deposition there is only minor differences present comparing this case with model runs under base case conditions.

It is concluded that deposition is important; however by neglecting deposition rate we

A pseudo-Lagrangian model study of the size distribution properties over Scandinavia

P. Tunved et al.

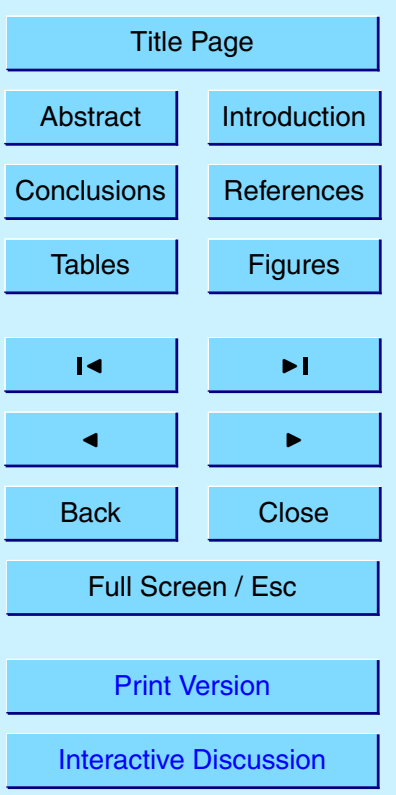


do not drastically change the result as compared with the base case. This indicates that deposition is of minor importance during this kind of transport and that the sensitivity to moderate changes in deposition rate is small.

\subsubsection{Case 4: Role of nucleation}

5 In this sensitivity case, we ran the model with nucleation disabled in order to evaluate the contribution of newly formed particles to the resulting size distribution observed at Värriö.

It is found that the resulting mass concentration in this test was $4.0 \mu \mathrm{g} / \mathrm{m}^{3}$ and the predicted number concentration was $1600 \mathrm{~cm}^{-3}$. Under base case conditions, integral 10 number concentration was predicted to be $1980 \mathrm{~cm}^{-3}$. The main difference in number concentration comparing the two cases is located in the nuclei-lower Aitken size range. It is thus rather clear that nucleation does not significantly change the result compared to the base case, which in turn implies that nucleation does not affect particles of larger size in the modelled case. However, this is not self evident. As shown in Sect. 3.3.1, an increase of the sulphuric acid source term by a factor of ten changes both aerosol mass and number significantly compared to the base case. Thus, the contribution of nucleation to the final distribution is highly dependent on the ratio of precursors and pre-existing aerosol. It is also clear that nucleation likely contributes to the population of small particles during transport.

\subsubsection{Case 5: Role of coagulation}

In order to study the evolution of the aerosol size distribution in the absence of coagulation, we need to assume that no nucleation occurs. Scavenging to pre-existing particles is clearly the most important loss mechanism of newly formed clusters, and thus including nucleation without coagulation would result in unrealistically high particle concentrations. On the other hand, disabling nucleation does not significantly alter the resulting size distribution compared to the base case as was seen in previous section.

A pseudo-Lagrangian model study of the size distribution properties over Scandinavia

P. Tunved et al.

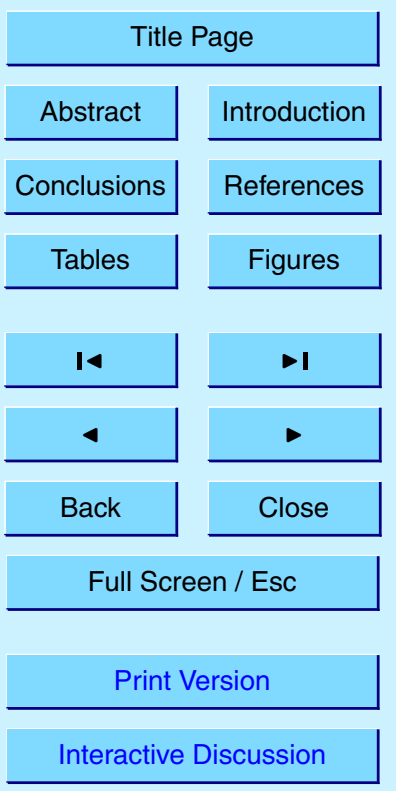


Thus, in this case we disabled both nucleation and coagulation.

When coagulation and nucleation are switched off in the model, the predicted number concentration is significantly higher than in the base case: $2400 \mathrm{~cm}^{-3}$ compared to $1980 \mathrm{~cm}^{-3}$. The location o the predominating Aitken mode is further shifted to smaller 5 sizes. As can be expected, the mass concentration is not significantly changed in this test. In the modelled case, coagulation seems to be the most important mechanism controlling the evolution of the number concentration.

\subsubsection{Case 6: Role of residual layer and boundary layer exchange}

The boundary layer evolution is crucial for a more realistic representation of aerosol

size distribution evolution. In the base case simulation, we applied a rather simplified, yet realistic model of the boundary layer dynamics. The use of a residual layer above the boundary layer along with corresponding fumigation and dilution effects is intuitively reasonable. Furthermore, it is much more accurate than assuming that all aerosol particles are confined to the boundary layer or than mixing with air devoid of particles when the boundary layer evolves during day time. In this section we test how the aerosol size distribution would evolve in absence of mixing.

As shown in lowermost frame of Fig. 9 the resulting size distribution derived from this test is significantly biased towards larger sizes. This result in overrepresentation of aerosol mass compared with base case simulations and produces an aerosol size distribution significantly apart from observations. This is mainly the result of higher terpene concentration since no dilution by mixing occurs. This results in increased aerosol growth if we assume similar yield of low volatile products from terpene oxidation as in base case conditions.
ACPD

4, 7757-7794, 2004

A pseudo-Lagrangian model study of the size distribution properties over Scandinavia

P. Tunved et al.

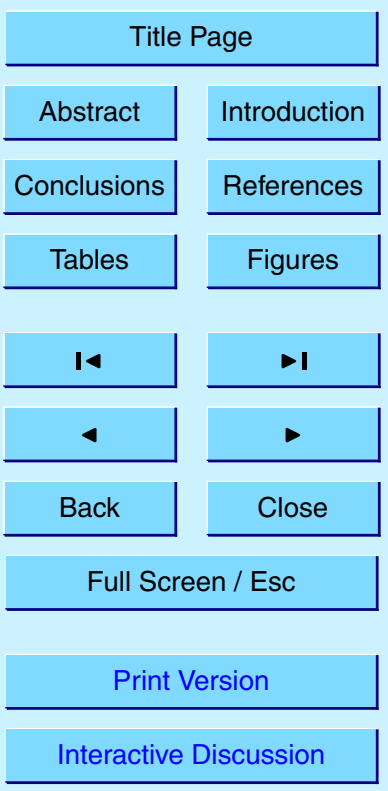




\section{Discussion}

We have explored how the aerosol size distribution evolves as northerly transport over Scandinavia take place. In the selected box-model approach we assume growth of the aerosol to be controlled by low volatile products from oxidation of terpenes and

5 sulphur dioxide. It is obvious that some condensable species in addition to sulphuric acid is necessary to accurately describe the size distribution evolution. In this study this species was represented by some condensable product from terpene oxidation. The idea of a link between aerosol mass accumulation and emissions from the forest offers straightforward connection between the characteristic environment over the 10 Nordic boreal region and observed aerosol properties. Organics may play an important role in contributing to aerosol mass and number with important implications for climate change. Already in 1960 Went recognized the fact that biogenic emissions may significantly contribute to the atmospheric aerosol burden. The importance of biogenic secondary organic aerosol (SOA) in atmospheric chemistry is further emphasized by e.g. Andrea and Crutzen (1997).

During recent years efforts have been put down to quantify the role of naturally emitted organics in the boreal region. Low volatile oxidation products of mono-terpenes have aroused as the most promising candidate for significant gas to particle conversion over the boreal forest (Janson et al., 2001; Spanke et al., 2001). Although it seems rather clear that the mono-terpenes do not contribute to the actual nucleation mechanism, it is likely that degradation of mono-terpenes constitute a significant source of low volatile hydrocarbons necessary to explain the observed growth rate of freshly formed particles (Jansson et al., 2001; Kulmala et al., 2001). Knowledge about the products formed from terpene oxidation however needs to be improved, regarding density, sur25 face tension and saturation vapour pressure. Also to be considered is the actual yield of condensable species from the oxidation of monoterpenes. Controlled experiments indicate a wide range of aerosol mass yields depending on oxidant and type of terpenes (e.g. Odum et al., 1996; Hoffmann et al., 1997). Yield is generally in the order of
ACPD

4, 7757-7794, 2004

A pseudo-Lagrangian model study of the size distribution properties over Scandinavia

P. Tunved et al.

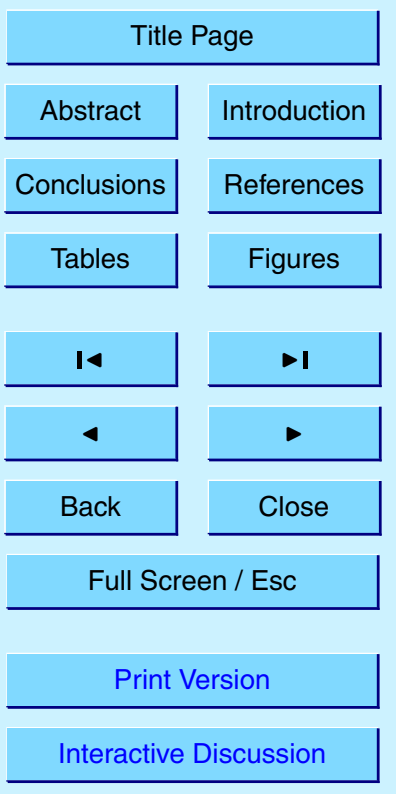


a few percent up to $50-60 \%$. Since an explicit knowledge concerning the mass yield is lacking we are thus confined to estimates of the yield under conditions valid over the Nordic countries. Assuming that terpenes actually participate in aerosol formation, it is evident from this study that an accurate determination thereof is mandatory.

$5 \quad$ Nucleation is not predicted contribute to number increase of $>10 \mathrm{~nm}$ particles to a large extent during northerly transport under selected base case conditions. This was shown both by simulations and observations. Nucleation does occur during the transport cases modelled, but does no result in integral number increase during transport. The potential of nucleation to contribute significantly to the overall number may in sim10 ple terms be defined by the relation of precursors of nucleating species versus the pre-existing aerosol (or condensational sink) an increased concentration of either $\mathrm{OH}$ or $\mathrm{SO}_{2}$ would favour a high apparent nucleation rate as shown in Sect. 3.3.1. This in consequence would lead to actual increase in integral aerosol number during transport. However, characteristic values of the $\mathrm{SO}_{2}$ concentration observed at Hyytiälä in 15 southerly winds ranges from $0.05-0.35 \mathrm{ppbv}$ (25th and 75 th percentile, respectively). Thus, concentrations of $\mathrm{SO}_{2}$ in the order of several ppbv's are not often encountered.

\section{Summary and conclusions}

We have investigated the evolution of aerosol size distribution as transport over Finland and Sweden from south to north occurs. The analysis is based on a pseudo20 Lagrangian assumption. As reference points for model input and output size distribution measurements from two stations have been used. Aspvreten $\left(58.8^{\circ} \mathrm{N}, 17.4^{\circ} \mathrm{E}\right)$ served as starting location for our analysis and Värrio $\left(67.46^{\circ} \mathrm{N}, 29.35^{\circ} \mathrm{E}\right)$ as the receptor station. The average transport time between the two stations is $85 \mathrm{~h}$. The aerosol dynamics was modelled using University of Helsinki Multicomponent Aerosol model
(UHMA, Korhonen et al., 2004). Twelve well-defined transport cases were selected from a one year data set. All cases describe transport under clear sky conditions. The transport mainly occurs over sparsely populated areas. Anthropogenic emissions
ACPD

4, 7757-7794, 2004

A pseudo-Lagrangian model study of the size distribution properties over Scandinavia

P. Tunved et al.

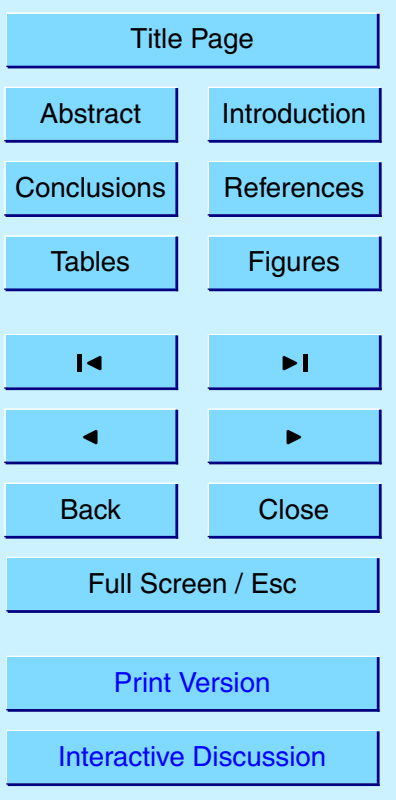


are likely to give only small contributions along the transport path. As a main subject of interest we have studied what processes determine the size distribution during the transport.

Simulations under base case conditions performed in this investigation show good 5 agreement with observations on average. Number concentration and mass concentration was overestimated by $10 \%$ on average. This indicates that aerosol growth as well as other dynamical processes is well represented by the model.

By performing sensitivity analysis of selected parameters we conclude following:

- The effect from dry deposition on the aerosol size distribution is small. By disabling dry deposition only minor changes in simulated aerosol size distribution was observed. We recognize dry deposition as being the only mechanism for removal of mass except dilution under clear sky conditions, but however conclude that the absolute magnitude of dry deposition effects on the aerosol size distribution over all is low.
- By investigating the response to changes in yield of condensable products from terpene oxidation we conclude that the sensitivity to changes in the yield is high. Under base case conditions a yield of condensable products from terpene oxidation of $13 \%$ was applied. This gave in many cases a nice agreement between simulated and observed size distributions. Assuming correct representation of terpene emissions and accurate estimates of concentration of major oxidants it is therefore likely that aerosol product yield from terpene oxidation is close to $10-15 \%$.

- Simulations and observations indicate that nucleation continuously occur during northerly transport, showing maximum amplitude during noon. The concentration of pre-existing particles is however large in modelled cases. This result in high condensation and coagulation sink, and consequently only a smaller fraction of newly nucleated particles will reach a size where they will remain as individual particles. Nucleation is however in many cases necessary to explain presence of
ACPD

$4,7757-7794,2004$

A pseudo-Lagrangian model study of the size distribution properties over Scandinavia

P. Tunved et al.

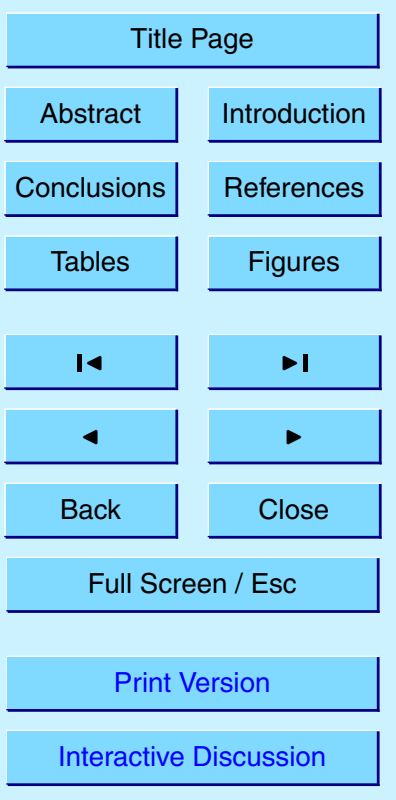

EGU 
small particles associated with observational data, but does not contribute to overall increased number concentration of larger particles during northerly transport under modelled conditions. As shown, the sensitivity to sulphuric acid generation rate is however obvious.

- Coagulation seems to be the main processes in controlling the observed reduction in aerosol number concentration in virtually all cases.

In total, although nucleation occasionally occurs, it does not generally lead to number increase during transport from Aspvreten to Värriö. Instead, as indicated by the modelled cases and observational data, transport from south to north will result in a number decrease in the Aitken size range, generally in conjunction with increased mass due to condensation growth of existing particles. The most important mechanism in reducing aerosol number is coagulation. Modelled cases with coagulation disabled showed poor agreement with measured size distributions at Värriö. Although we believe that the aerosol dynamic aspects of the model study are correct, we are likely to need im-

\section{boundary layer as well as the exchange with the free troposphere.}

Conclusively, this investigation have explored the possibilities of using rather simple approaches in order to achieve a Lagrangian perspective to a unique data set comprising size distribution measurements at several stations in the Nordic countries. The approach proved successful. Besides the existing size distribution observations, equally ambitious measurements of chemical properties of the aerosol would greatly improve our current understanding of the determining processes controlling aerosol size distribution, and pave way for a more detailed investigation of the interplay between water vapour and aerosols.

25 Acknowledgements. This work was funded by the ASTA programme (International and National Abatement Strategies for Transboundary Air Pollution) of the MISTRA research foundation (Swedish Foundation for Strategic Environmental Research), Nordic Council of Ministers (NMR) and the Swedish Environmental Protection Agency, Environmental Monitoring Programme.
ACPD

4, 7757-7794, 2004

A pseudo-Lagrangian model study of the size distribution properties over Scandinavia

P. Tunved et al.

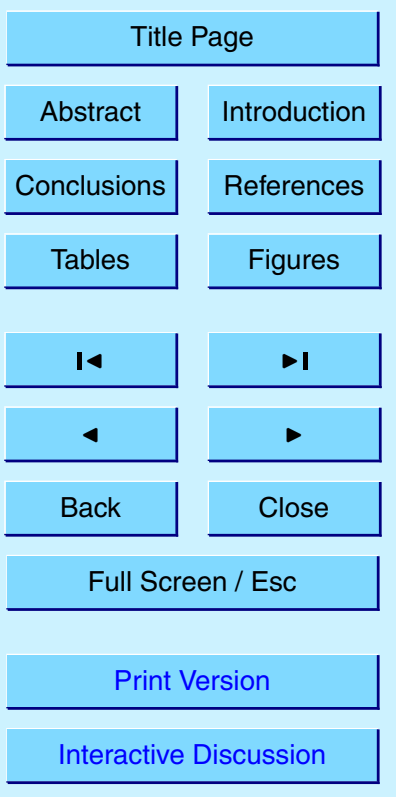


The authors gratefully acknowledge the NOAA Air Resources Laboratory (ARL) for the provision of the HYSPLIT transport and dispersion model used in this publication.

\section{References}

Andreae, M. O. and Crutzen, P. J.: Atmospheric aerosols: biogeochemical sources and role in atmospheric chemistry, Science, 276, 1052-1058, 1997.

Boy, M., Rannik, U., Lehtinen, K. E. J., Tarvainen, V., Hakola, H., and Kulmala, M.: Nucleation events in the continental boundary layer: Long-term statistical analyses of aerosol relevant characteristics, J. Geophys. Res., 108, 4667, doi:10.1029/2003JD003838, 2003.

Derwent, R. G. and Jenkin, M. E.: Hydrocarbon involvement in photochemical ozone formation in Europe, AERE Report R13736 (HMSO), London, 1990.

Draxler, R. R. and Hess, G. D.: Description of the Hysplit_4 modelling system, NOAA Tech Memo, ERL, ARL-224, 1997.

Draxler, R. R. and Rolph, G. D.: HYSPLIT (HYbrid Single-Particle Lagrangian Integrated Trajectory) Model access via NOAA ARL READY Website (http://www.arl.noaa.gov/ready/hysplit4. html), NOAA Air Resources Laboratory, Silver Spring, MD, 2003.

European Commission: Biogenic VOC emissions and photochemistry in the boreal regions of Europe - Biphorep, Edited by Tuomas Laurila and Virpi Lindfors, ISBN 92-828-6990-3, 127-150, 1999.

Hakola, H., Tarvainen, V., Laurila, T., Hiltunen, V., Hellen, H., and Keronen, P.: Seasonal variation of VOC concentrations above a boreal coniferous forest, Atm. Env., 37, 1623-1634, 2003.

Hoffmann, T., Odum, J. R., Bowman, F., Collins, D., Klockow, D., Flagan, R. C., and Seinfeld, J. H.: Formation of organic aerosols from the oxidation of biogenic hydrocarbons, J. Atm. Chem., 26, 189-222, 1997.

IPCC: in: Houghton, J.T., Ding, Y., Griggs, D.J., Noguer, M. et al. Climate Change 2000 - The Science of Climate Change, Cambridge University Press, Cambridge, 2001.

Janson, R., Rosman, K., Karlsson, A., and Hansson, H. C.: Biogenic emissions and gaseous precursors to forest aerosols, Tellus B, 53, 423-440, 2001.

Kerminen, V. M., Pirjola, L., and Kulmala, M.: How significantly does coagulational scavenging limit atmospheric particle production?, J. Geophys. Res., 106, 24 119-24 125, 2001.

\section{A pseudo-Lagrangian model study of the size distribution properties over Scandinavia}

P. Tunved et al.

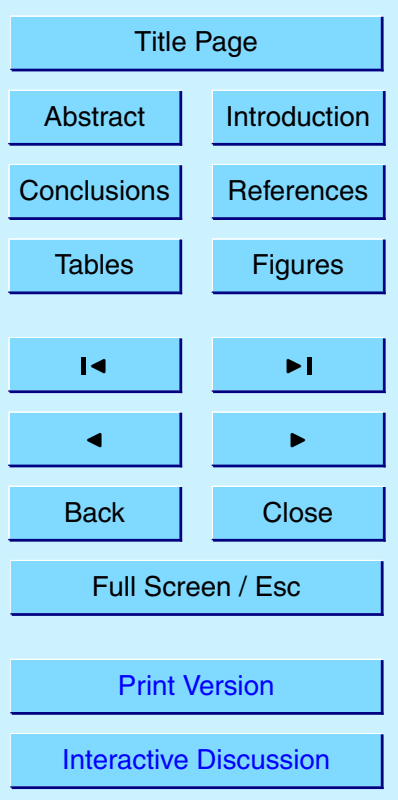


Knutson, E. O. and Whitby, K.: Aerosol classification by electric mobility: apparatus theory and applications, J. Aerosol Sci., 443-451, 1975.

Korhonen, H., Lehtinen, K. E. J., and Kulmala, M.: Multicomponent aerosol dynamics model UHMA: model development and validation, Atmos. Chem. Phys., 4, 757-771, 2004,

5 SRef-ID: 1680-7324/acp/2004-4-757.

Kulmala, M., Toivonen, A., Mäkeleä, J. M., and Laaksonen, A.: Analysis of the growth of nucleation mode particles observed in Boreal forest, Tellus B, 50, 449-462, 1998.

Kulmala, M., Rannik, Ü., Pirjola, L., Dal Maso, M., Karimäki, J., Asmi, A., Jäppinen, A., Karhu, V., Korhonen, H., Malvikko, S.-P., Puustinen, A., Raittila, J., Romakkaniemi, S., Suni, T., Yli-Kovisto, S., Pateero, J., Hari, P., and Vesala, T.: Characterization of atmospheric trace gases and aerosol composition at forest sites in southern and northern Finland using back trajectories, Bor. Env. Res., 5, 315-336, 2000.

Kulmala, M., Hämeri, K., Aalto, P. P., Mäkelä, J. M., Pirjola, L., Nilsson, E. D., Buzorius, G., Rannik, U., Dal Maso, M., Seidl, W., Hoffman, T., Janson, R., Hansson, H.C., Viisanen, Y., Laaksonen, A., and O'Dowd, C. D.: Overview of the international project on biogenic aerosol formation in the boreal forest (BIOFOR), Tellus B, 53, 324-343, 2001.

Kulmala, M., Vehkamäki, H. Petajda, T., Dal Maso, M., Lauri, A., Kerminen, V. M., Birmili, W., and McMurry, P. H.: Formation and growth rates of ultrafine atmospheric particles: a review of observations, J. Aer. Sci., 35, 143-176, 2004a.

Kulmala, M., Kerminen, V. M., Anttila, T., Laaksonen, A., and O'Dowd, C. D.: Organic aerosol formation via sulphate cluster activation, J. Geophys. Res., 109, D04205, 2004b.

Künzli, N. Kaiser, R., Medina, S., Studnicka, M., Chanel, O., Filliger, P., Herry, M., Horak, F., Puybonnieux-Texier, V., Quenel, P., Schneider, J., Seethaler, R., Vergnaud, J. C., and Sommer, H.: Public-health impact of outdoor and traffic-related air pollution: a European assessment, Lancet, 356, 795-801, 2000.

Laakso, L., Petäjä, T., Lehtinen, K. E. J., Kulmala, M., Paatero, J., Hõrrak, U., Tammet, H., and Joutsensaari, J.: Ion production rate in a boreal forest based on ion, particle and radiation measurements, Atmos. Chem. Phys. Discuss., 4, 3947-3973, 2004,

SRef-ID: 1680-7375/acpd/2004-4-3947.

30 Leaitch, W. R., Bottenheim, J. W., Biesenthal, T. A., Li, S. M., Liu, P. S. K., Asalian, K., DryfhoutClark, H., Hopper, F., and Brechtel, F.: A case study of gas-to-particle conversion in an eastern Canadian forest, J. Geophys. Res., 104, 8095-8111, 1999.

Mäkelä, J. M., Aalto, P., Jokinen, V., Pohja, T., Nissinen, A., Palmroth, S., Markkanen, T.,

\section{A pseudo-Lagrangian model study of the size distribution properties over Scandinavia}
P. Tunved et al.

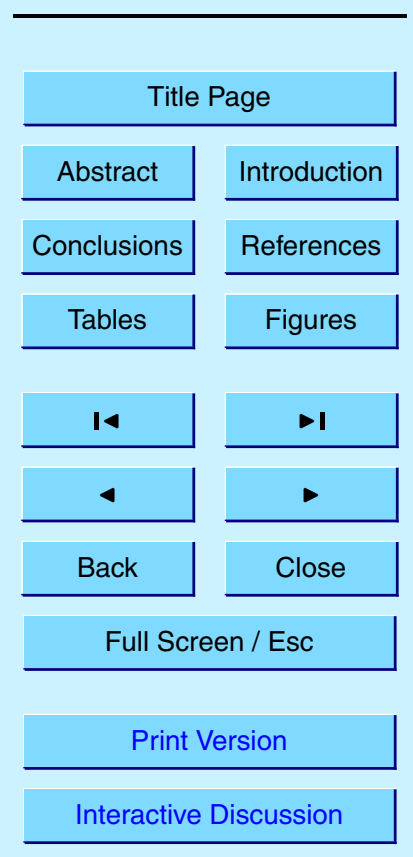


Seitsonen, K., Lihavainen, H., and Kulmala, M.: Observations of ultrafine aerosol particle formation and growth in boreal forest, Geophys. Res. Lett., 24, 1219-1222,1997.

Mäkelä, J. M., Dal Maso, M., Pirjola, L., Keronen, P., Laakso, L., Kulmala, M., and Laaksonen, A.: Characteristics of the aerosol particle formation events observed at a boreal forest site in 5 southern Finland, Boreal Env. Res., 4, 299-313, 2000.

Nilsson, E. D., Rannik, U., Kulmala, M., Buzorius, G., and O'Dowd, C. D.: Effects of continental boundary layer evolution, convection, turbulence and entrainment, on aerosol formation, Tellus B, 53, 441-461, 2001a.

Nilsson, E. D., Paatero, J., and Boy, M.: Effects of air masses and synoptic weather on aerosol formation in the continental boundary layer, Tellus B, 53, 462-478, 2001b.

O'Dowd, C. D., Aalto, P., Hameri, K., Kulmala, M., and Hoffmann, T.: Aerosol formation Atmospheric particles from organic vapours, Nature, 416, 497-498, 2002.

Odum, J. R., Hoffmann, T., Bowman, F., Collins, D., Flagan, R. C., and Seinfeld, J. H.: Gas/particle partitioning and secondary organic aerosol yields Environ. Sci. Tech., 30, 25802585, 1996.

Rannik, U., Aalto, P., Keronen, P., Vesala, T., and Kulmala, M.: Interpretation of aerosol particle fluxes over a pine forest: Dry deposition and random errors, J. Geophys. Res., 108, 4544, doi:10.1029/2003JD003542, 2003.

Slinn, W. G. N.: Parameterizations for resuspension and for wet and dry deposition of particles and gases for use in radiation dose calculations, Nuclear Safety, 19, 205-219, 1978.

Spanke, J., Rannik, U., Forkel, R., Nigge, W., and Hoffmann, T.: Emission fluxes and atmospheric degradation of monoterpenes above a boreal forest: field measurements and modelling, Tellus, 53, 406-422, 2001.

Tunved, P., Hansson, H. C., Kulmala, M., Aalto, P., Viisanen, Y., Karlsson, H., Kristensson, A., Swietlicki, E., Dal Maso, M., Ström, J., and Komppula, M.: One-year boundary layer aerosol size distribution data from five Nordic background stations, Atmos. Chem. Phys., 3, 21832205, 2003,

SRef-ID: 1680-7324/acp/2003-3-2183.

Twomey, S. A.: Pollution and the planetary albedo, Atmos. Environ., 8, 1251-1256, 1974.

ACPD

4, 7757-7794, 2004

A pseudo-Lagrangian model study of the size distribution properties over Scandinavia

P. Tunved et al.

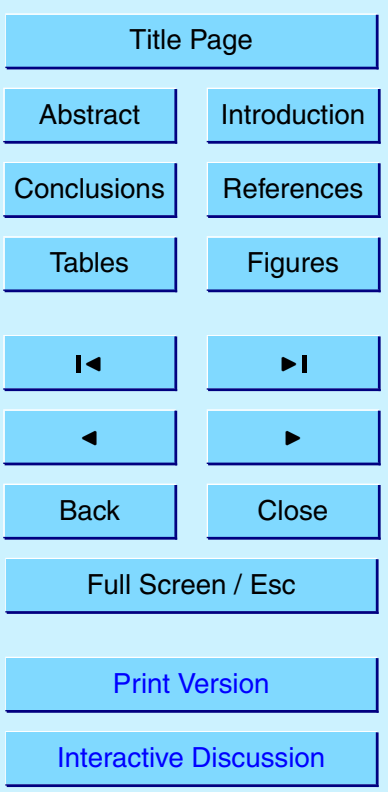




\section{ACPD}

4, 7757-7794, 2004

Table 1. Base case conditions. All units in ppb. ( ${ }^{1}$ Data from monthly average concentration of gases observed at Hyytiälä, ${ }^{2}$ Terpene emissions from pine and spruce according to Lindfors et al., 1999. ${ }^{3}$ From Janson et al., 2001).

\begin{tabular}{ccccccccccc}
\hline $\begin{array}{l}\text { Para- } \\
\text { meter }\end{array}$ & $\mathrm{O}_{3}$ & $\mathrm{NO}_{2}$ & $\mathrm{NO}$ & $\mathrm{HCHO}$ & $\mathrm{CH}_{4}$ & $\mathrm{CO}$ & $\mathrm{SO}_{2}$ & $\mathrm{NH}_{3}$ & Terpenes & $\begin{array}{c}\text { Meteorological } \\
\text { parameters }\end{array}$ \\
\hline & $30-40^{1}$ & $1-2^{1}$ & $\begin{array}{c}\text { from } \\
\mathrm{NO}_{2}\end{array}$ & $0.4^{3}$ & $1700^{3}$ & $150^{3}$ & $0.1-0.2^{1}$ & 0.025 & $\begin{array}{c}\text { temperature } \\
\text { dependent } \\
\text { emissions }{ }^{2}\end{array}$ & $\begin{array}{c}\text { trajectory } \\
\text { model } \\
15 \% \text { yield of } \\
\text { condensable } \\
\text { products } \\
\text { assumed }\end{array}$ \\
\hline
\end{tabular}

\section{A pseudo-Lagrangian model study of the size distribution properties over Scandinavia \\ P. Tunved et al.}

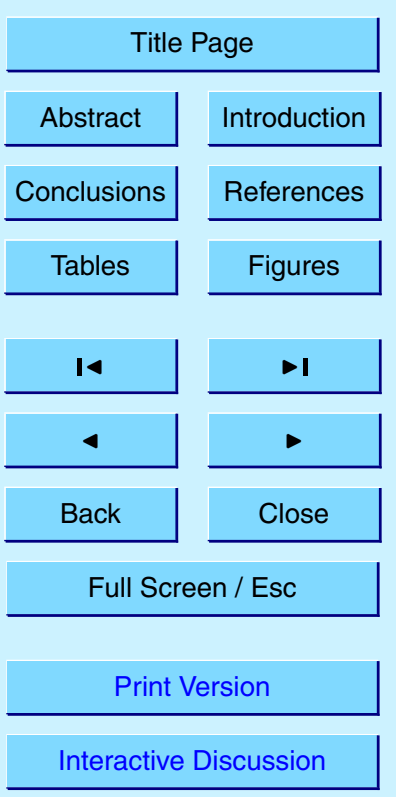




\section{ACPD}

4, 7757-7794, 2004

Table 2. Observed and modelled number $\left(\mathrm{cm}^{-3}\right)$ and mass concentration $\left(\mu \mathrm{g} / \mathrm{m}^{3}\right)$ at Värriö for model runs under base case conditions.

\begin{tabular}{|c|c|c|c|c|c|c|c|c|c|c|c|c|c|}
\hline & & $\begin{array}{c}\text { Case } \\
\text { A }\end{array}$ & $\begin{array}{c}\text { Case } \\
\text { B }\end{array}$ & $\begin{array}{c}\text { Case } \\
\text { C }\end{array}$ & $\begin{array}{c}\text { Case } \\
\text { D }\end{array}$ & $\begin{array}{c}\text { Case } \\
\text { E }\end{array}$ & $\begin{array}{c}\text { Case } \\
\mathrm{F}\end{array}$ & $\begin{array}{c}\text { Case } \\
\text { G }\end{array}$ & $\begin{array}{c}\text { Case } \\
\mathrm{H}\end{array}$ & $\begin{array}{c}\text { Case } \\
\text { I }\end{array}$ & $\begin{array}{c}\text { Case } \\
\mathrm{J}\end{array}$ & $\begin{array}{c}\text { Case } \\
\mathrm{K}\end{array}$ & $\begin{array}{c}\text { Case } \\
\text { L }\end{array}$ \\
\hline \multirow{2}{*}{$\begin{array}{l}\text { Mass, } \mathrm{mg} / \mathrm{m}^{3} \\
\left(\rho=1.5 \mathrm{~g} / \mathrm{cm}^{3}\right)\end{array}$} & Observation & 6.0 & 4.6 & 4.0 & 2.2 & 6.0 & 4.7 & 4.0 & 2.7 & 6.6 & 4.9 & 1.3 & 2.4 \\
\hline & Model & 3.7 & 3.5 & 3.8 & 4.1 & 2.8 & 3.0 & 3.6 & 4.3 & 3.2 & 3.7 & 3.5 & 3.8 \\
\hline \multirow{2}{*}{$\begin{array}{l}\text { Number } \\
\left(\mathrm{cm}^{-3}\right)\end{array}$} & Observation & 1435 & 1182 & 1777 & 1364 & 1172 & 1378 & 1554 & 1238 & 2035 & 1799 & 606 & 610 \\
\hline & Model & 1980 & 1161 & 1086 & 968 & 1768 & 1386 & 1394 & 1114 & 1752 & 1980 & 1106 & 1009 \\
\hline
\end{tabular}

\section{A pseudo-Lagrangian model study of the size distribution properties over Scandinavia \\ P. Tunved et al.}

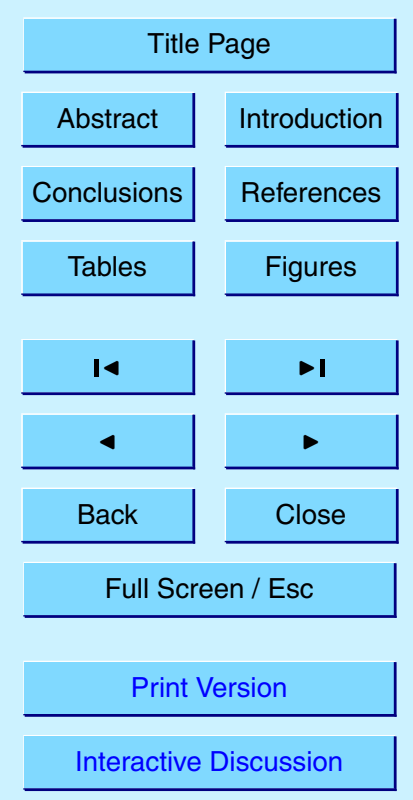




\section{ACPD}

4, 7757-7794, 2004

A pseudo-Lagrangian model study of the size distribution properties over

Scandinavia

Table 3. Summary of sensitivity tests performed.

P. Tunved et al.

\begin{tabular}{ccccccc}
\hline & Case 1 & Case 2 & Case 3 & Case 4 & Case 5 & Case 6 \\
\hline $\begin{array}{c}\text { Deviation } \\
\text { from base } \\
\text { case }\end{array}$ & $\begin{array}{c}\mathrm{OH}^{\text {increased }} \mathrm{SO}_{2} \\
\text { an order of } \\
\text { magnitude }\end{array}$ & $\begin{array}{c}\text { Yield of } \\
\text { COV } \\
\text { altered } \\
\text { between }\end{array}$ & $\begin{array}{c}\text { Deposition } \\
\text { disabled } \\
0.03 \text { and 0.25 }\end{array}$ & $\begin{array}{c}\text { Nucleation } \\
\text { disabled } \\
\text { coagulation } \\
\text { disabled }\end{array}$ & $\begin{array}{c}\text { Nucleation } \\
\text { and } \\
\text { dynamics } \\
\text { modified }\end{array}$ & $\begin{array}{c}\text { Boundary } \\
\text { layer }\end{array}$ \\
& & & & & & \\
\hline
\end{tabular}

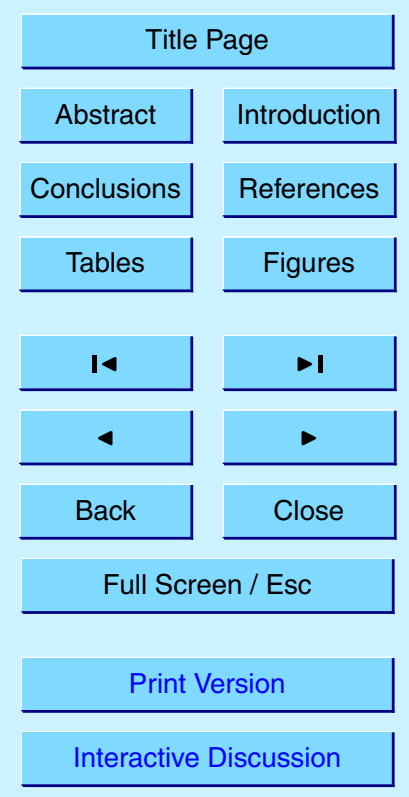




\section{ACPD}

4, 7757-7794, 2004

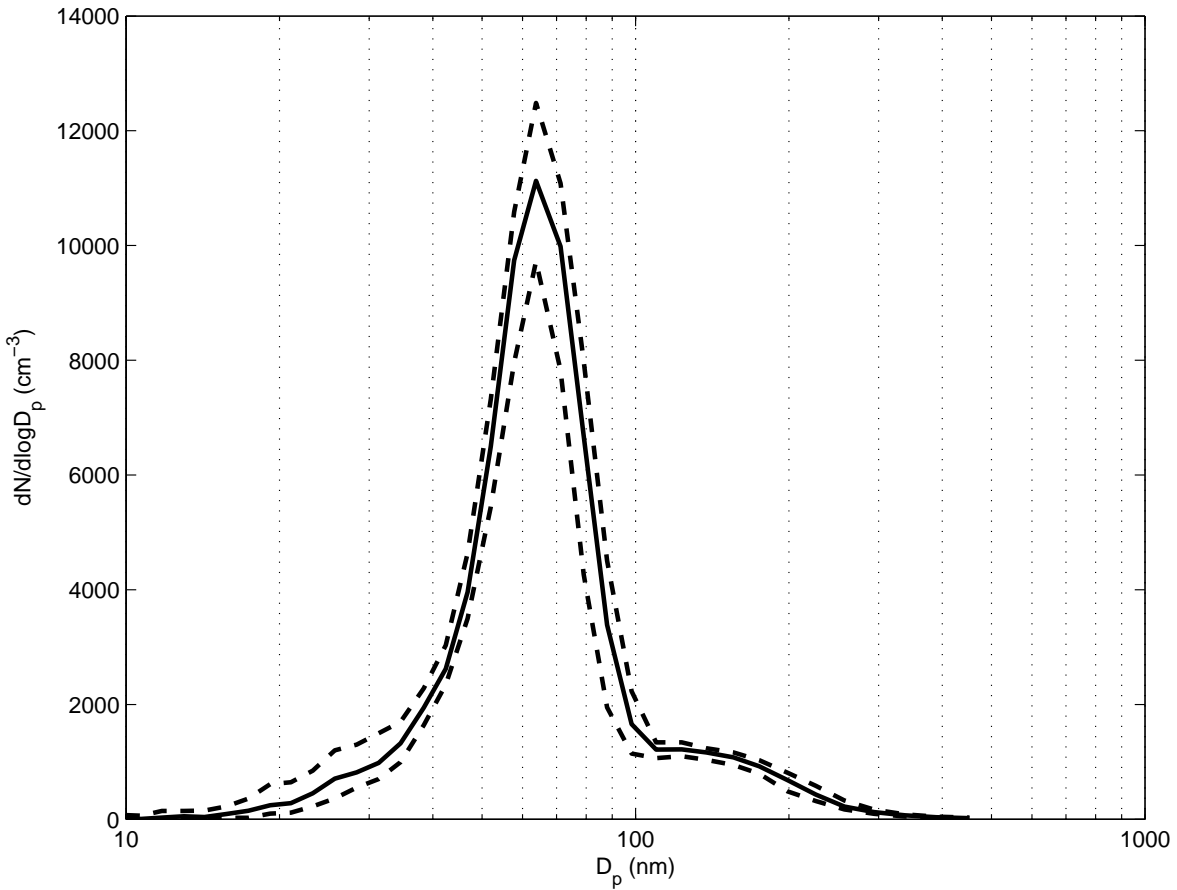

A pseudo-Lagrangian model study of the size distribution properties over Scandinavia

P. Tunved et al.

\section{Title Page}

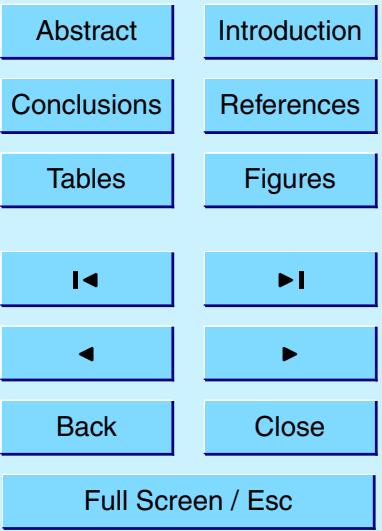
26 August 2000. (75 h before the air arrives Värriö according to trajectory analysis). Quartile ranges indicated by dashed lines.

Print Version

Interactive Discussion 


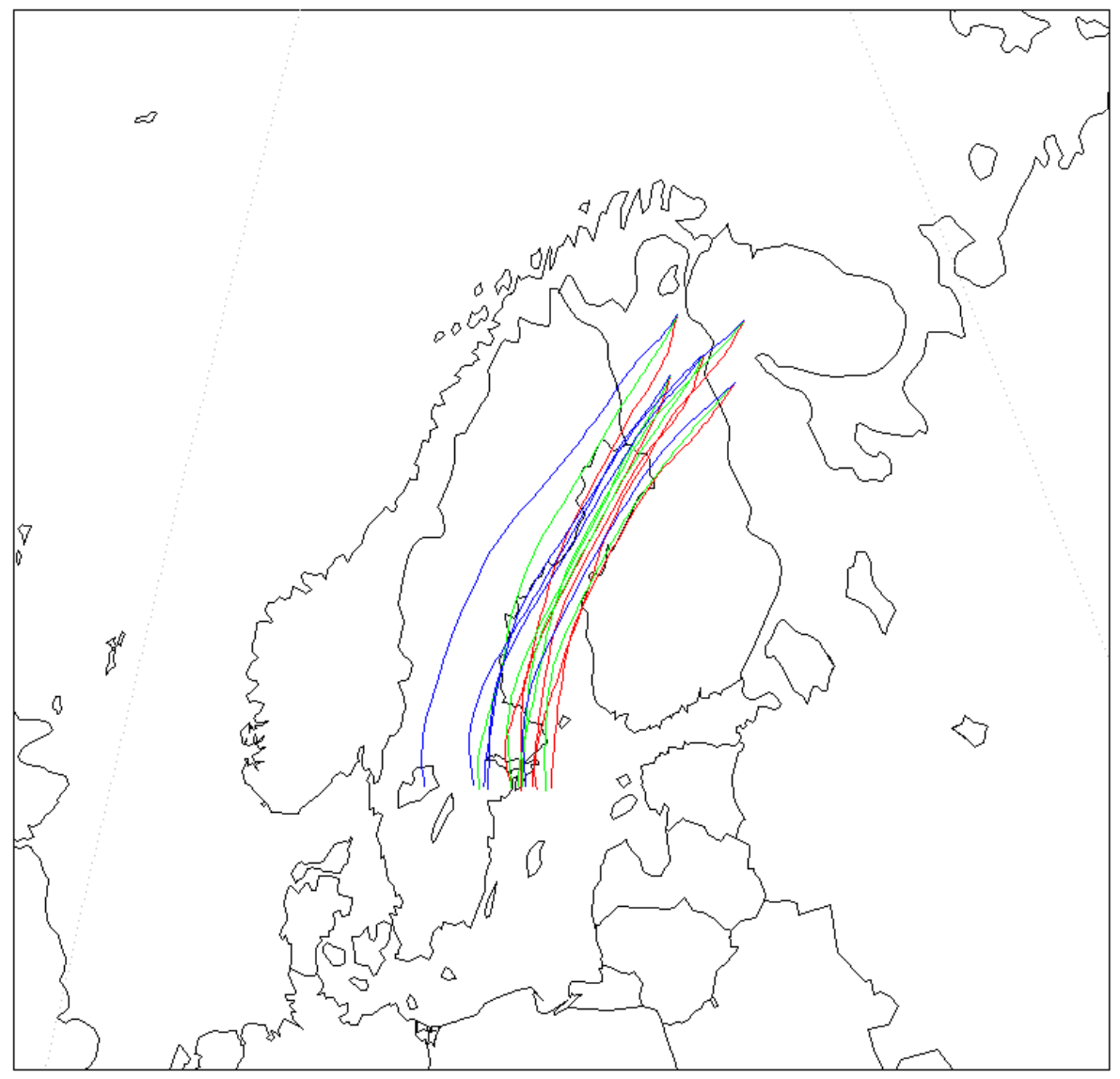

ACPD

4, 7757-7794, 2004

A pseudo-Lagrangian model study of the size distribution properties over Scandinavia

P. Tunved et al.

Title Page

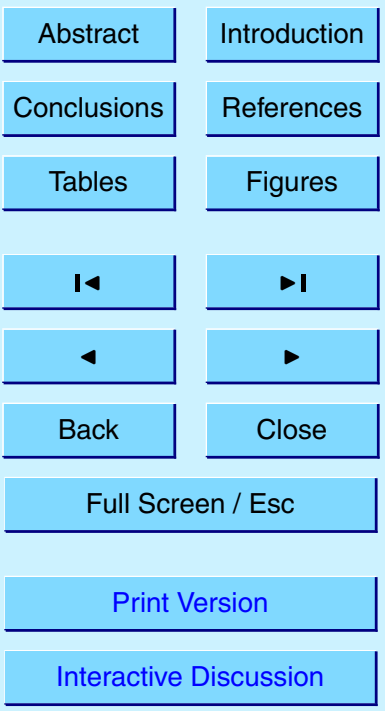

Fig. 2. Transport to Värriö and surroundings during 05:00 UTC, 29 August 2000. Trajectories are calculated at 10 (red), 100 (green) and $200 \mathrm{~m}$ (blue) to cover boundary layer transport pattern. Displayed are trajectories calculated for the receptor station Värriö as well as four other trajectories for the same arrival time defining a square around the station. 


\section{ACPD}

4, 7757-7794, 2004

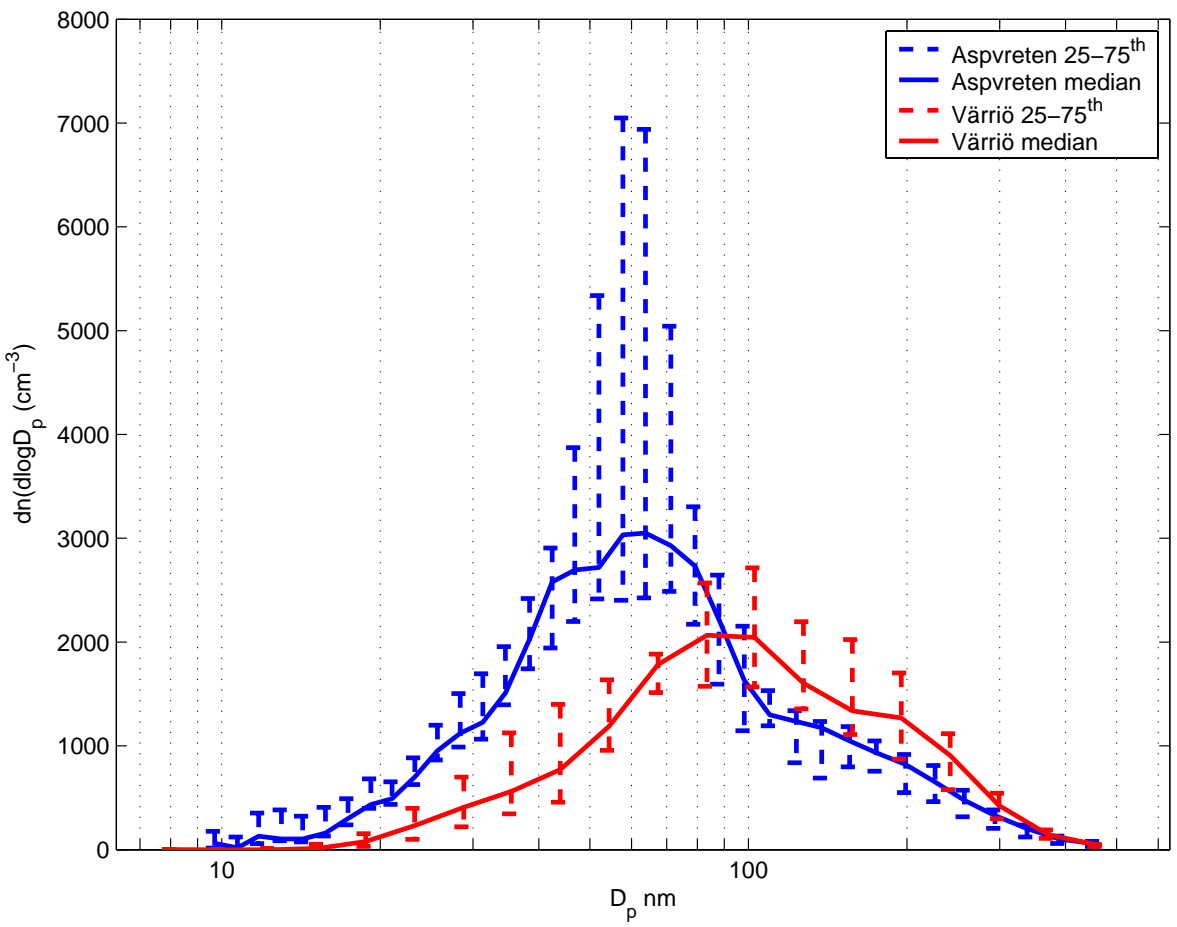

A pseudo-Lagrangian model study of the size distribution properties over Scandinavia

P. Tunved et al.

\section{Title Page}

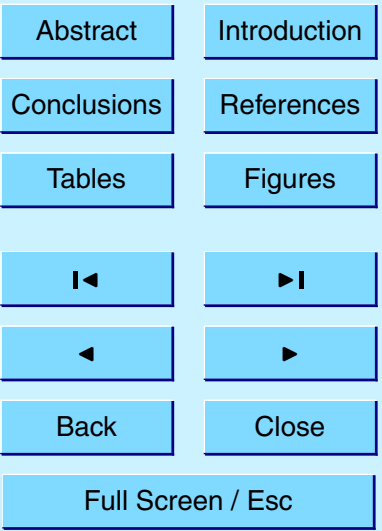

between Värriö and Aspvreten. Median and quartile ranges are indicate for both stations.

Print Version

Interactive Discussion 


\section{ACPD}
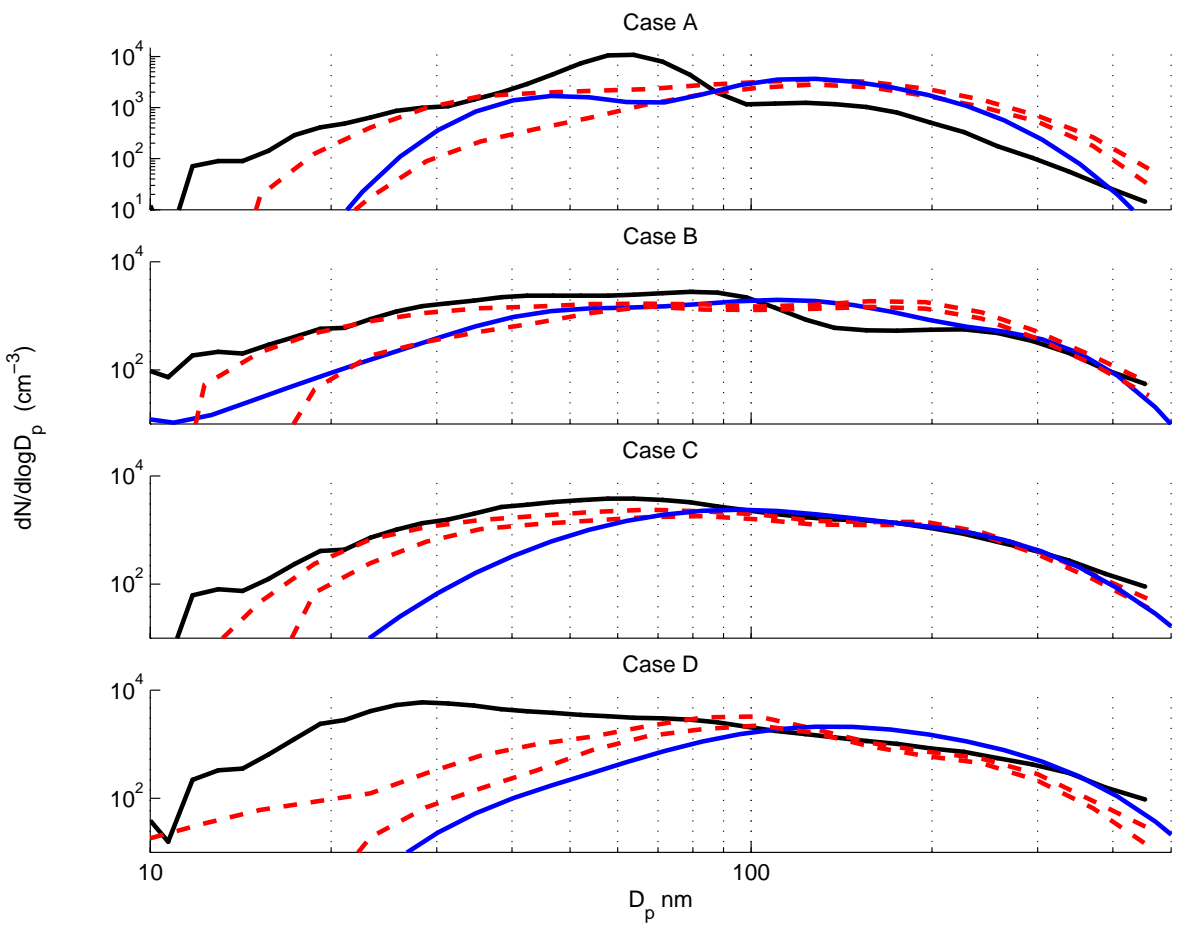

Fig. 4. Three selected cases from the modelled and observed size distribution data $\left(d N / d \log D_{p}\right.$, $\mathrm{cm}^{-3}$ ) resulting from transport between Aspvreten and Värriö. Red dashed line indicate quartile ranges of observational data, black solid line correspond to the initial aerosol size distribution and blue solid line corresponds to simulated aerosol size distribution.

4, 7757-7794, 2004

A pseudo-Lagrangian model study of the size distribution properties over Scandinavia

P. Tunved et al.

Title Page

\begin{tabular}{|c|c|}
\hline Abstract & Introduction \\
\hline Conclusions & References \\
\hline Tables & Figures \\
\hline 14 & $\rightarrow 1$ \\
\hline 4 & - \\
\hline Back & Close \\
\hline \multicolumn{2}{|c|}{ Full Screen / Esc } \\
\hline \multicolumn{2}{|c|}{ Print Version } \\
\hline Interactiv & iscussion \\
\hline
\end{tabular}




\section{ACPD}

4, 7757-7794, 2004

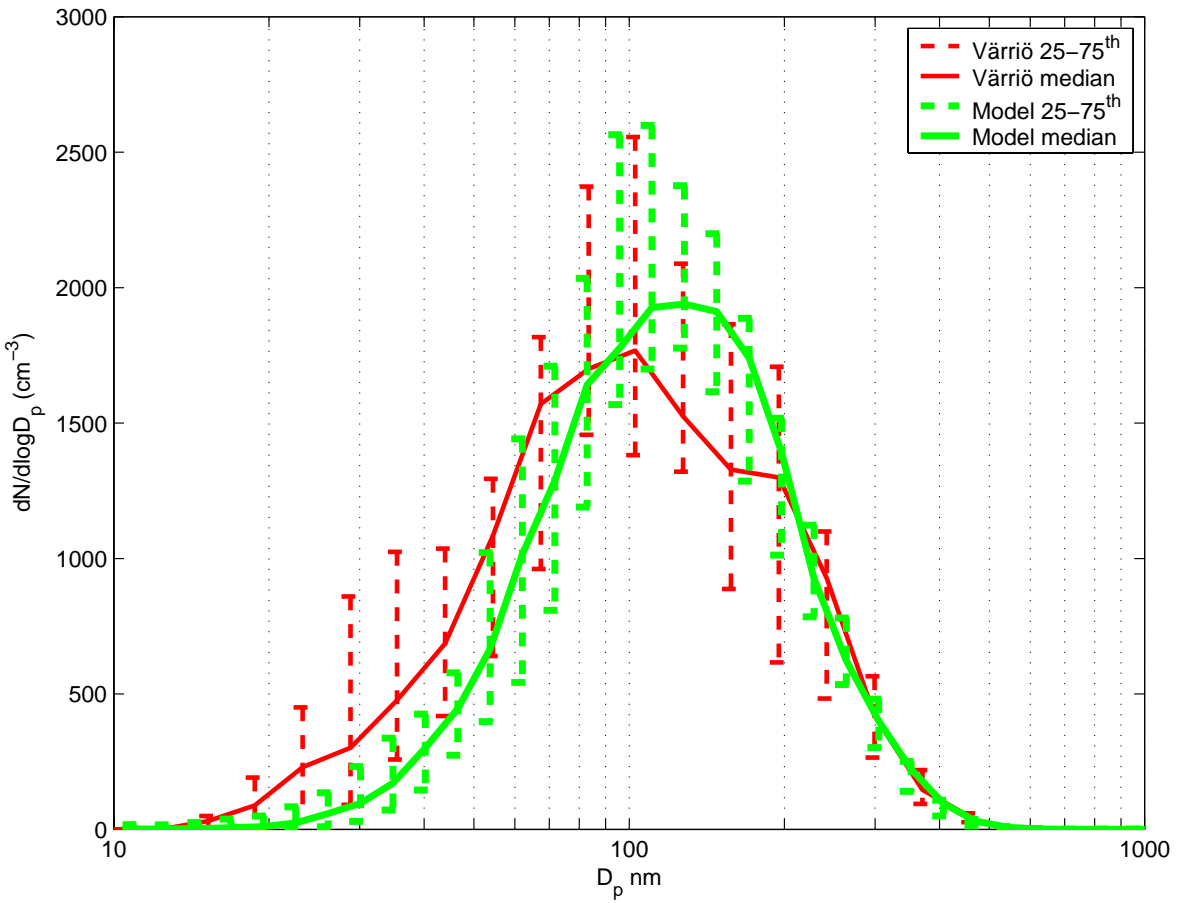

A pseudo-Lagrangian model study of the size distribution properties over Scandinavia

P. Tunved et al.

\section{Title Page}

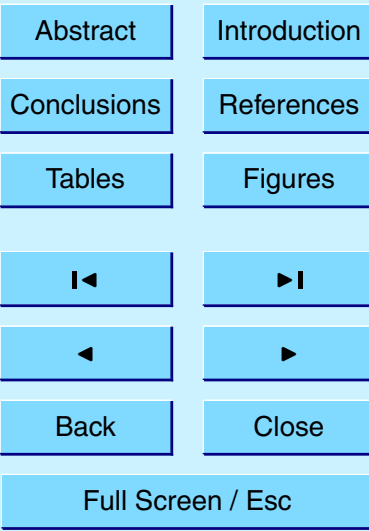

Fig. 5. Median size distribution properties $\left(\mathrm{dN} / \mathrm{d} \log \mathrm{D}_{\mathrm{p}}, \mathrm{cm}^{-3}\right)$ and model prediction of the resulting aerosol size distribution at Värriö. 12 cases considered. Average transport time is $85 \mathrm{~h}$.

Print Version

Interactive Discussion 


\section{ACPD}

4, 7757-7794, 2004

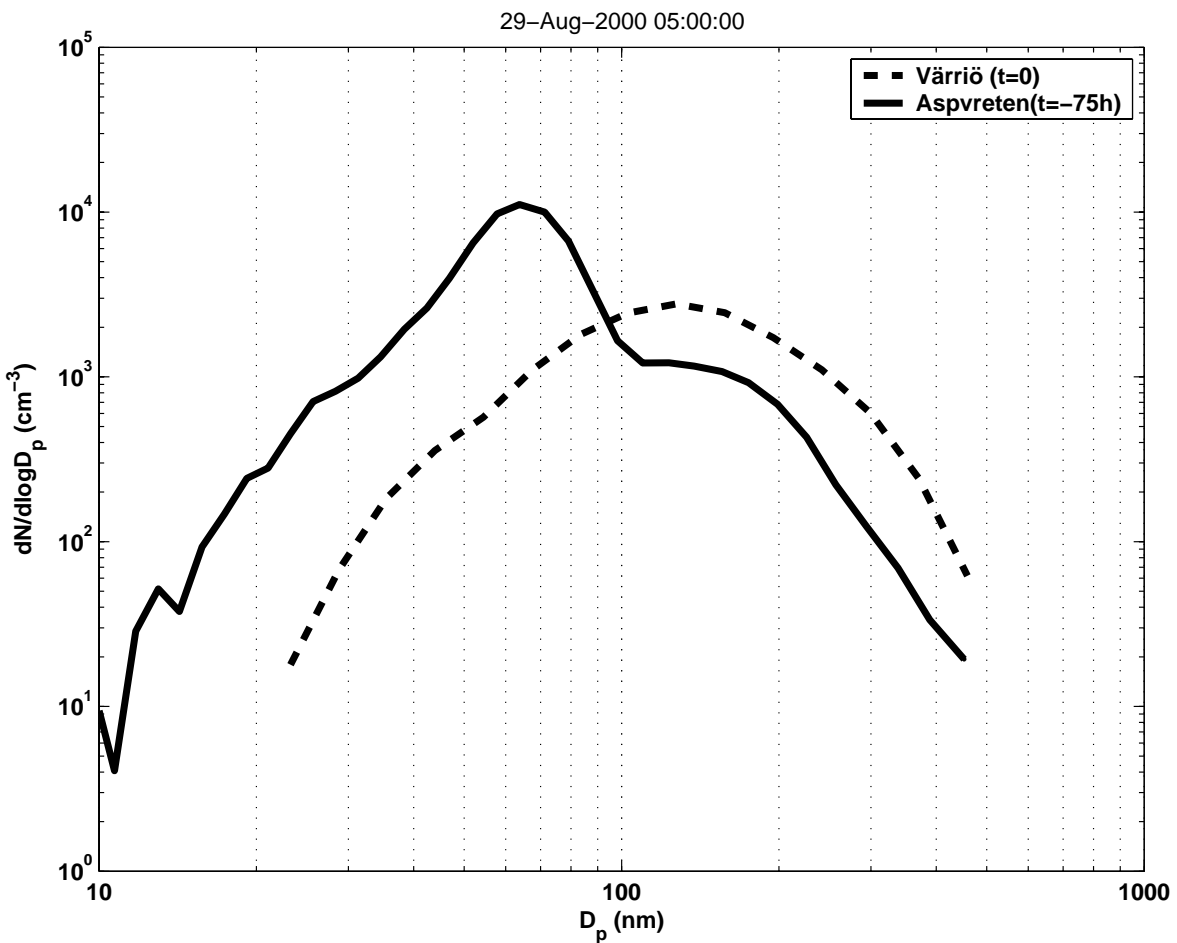

A pseudo-Lagrangian model study of the size distribution properties over Scandinavia

P. Tunved et al.

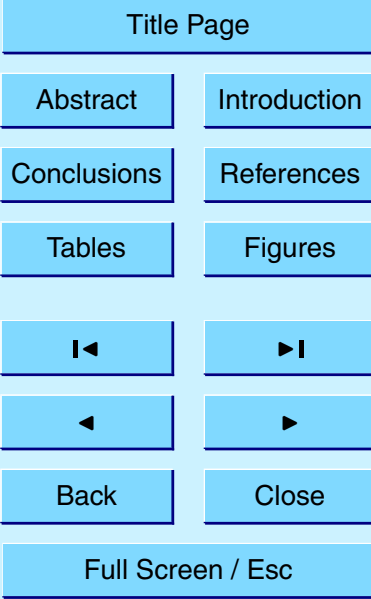

Fig. 6. Observed size distribution at Aspvreten (solid line) $77 \mathrm{~h}$ before it arrives Värriö (dashed line).

Print Version 


\section{ACPD}

4, 7757-7794, 2004

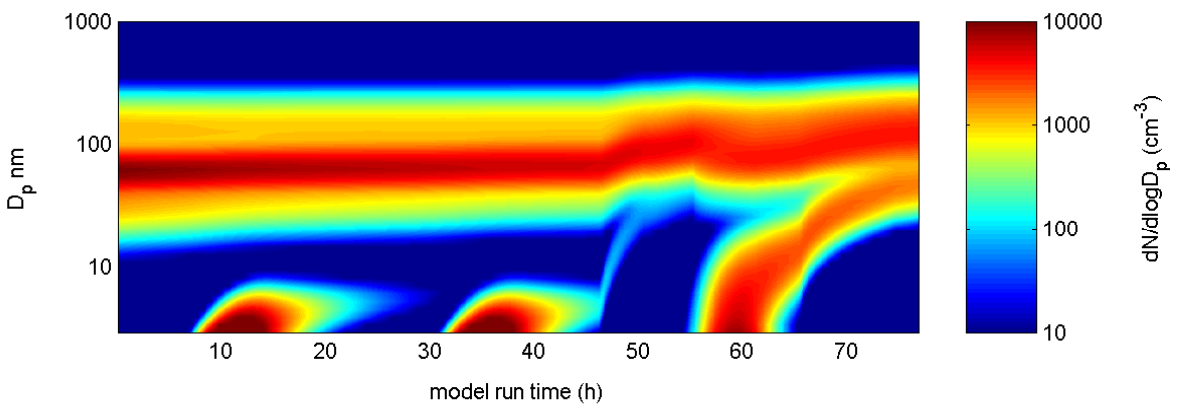

\section{A pseudo-Lagrangian model study of the size distribution properties over Scandinavia \\ P. Tunved et al.}
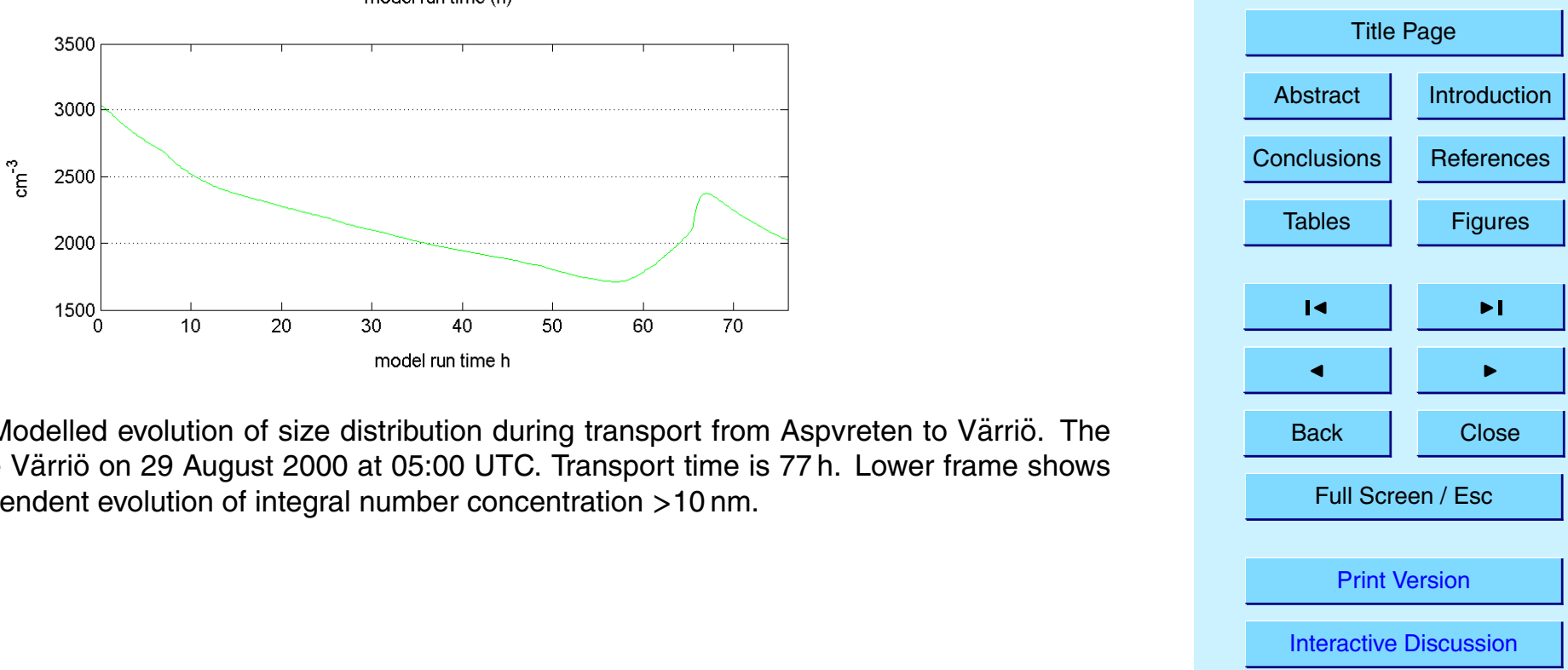

Fig. 7. Modelled evolution of size distribution during transport from Aspvreten to Värriö. The air arrive Värriö on 29 August 2000 at 05:00 UTC. Transport time is $77 \mathrm{~h}$. Lower frame shows time dependent evolution of integral number concentration $>10 \mathrm{~nm}$. 


\section{ACPD}

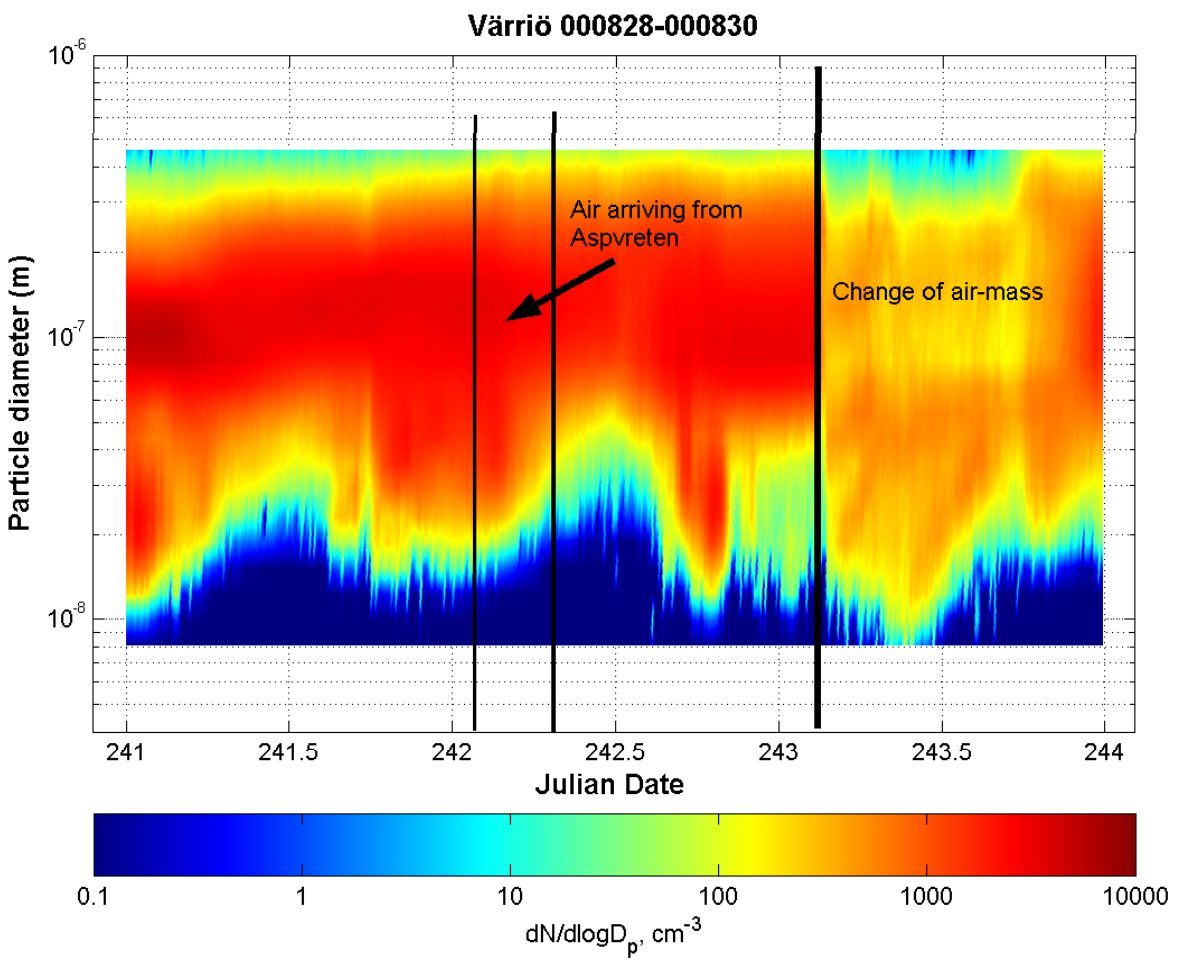

4, 7757-7794, 2004

\section{A pseudo-Lagrangian model study of the size distribution properties over Scandinavia \\ P. Tunved et al.}

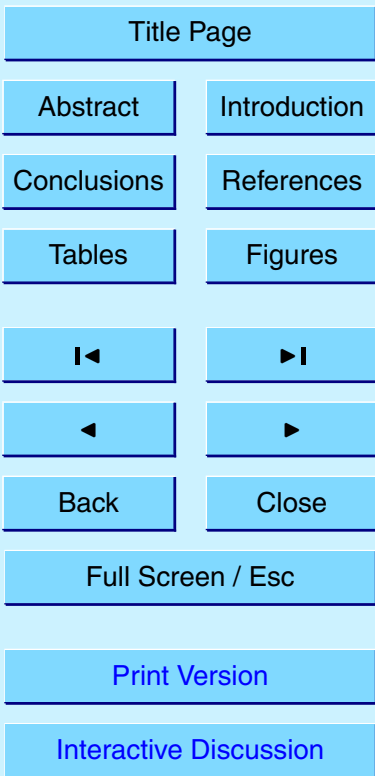




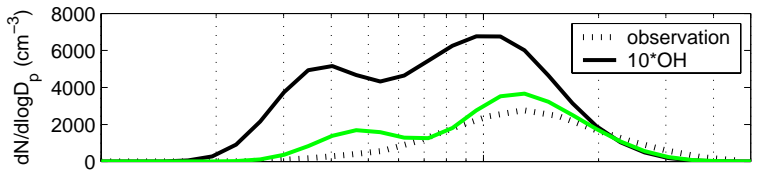

ACPD
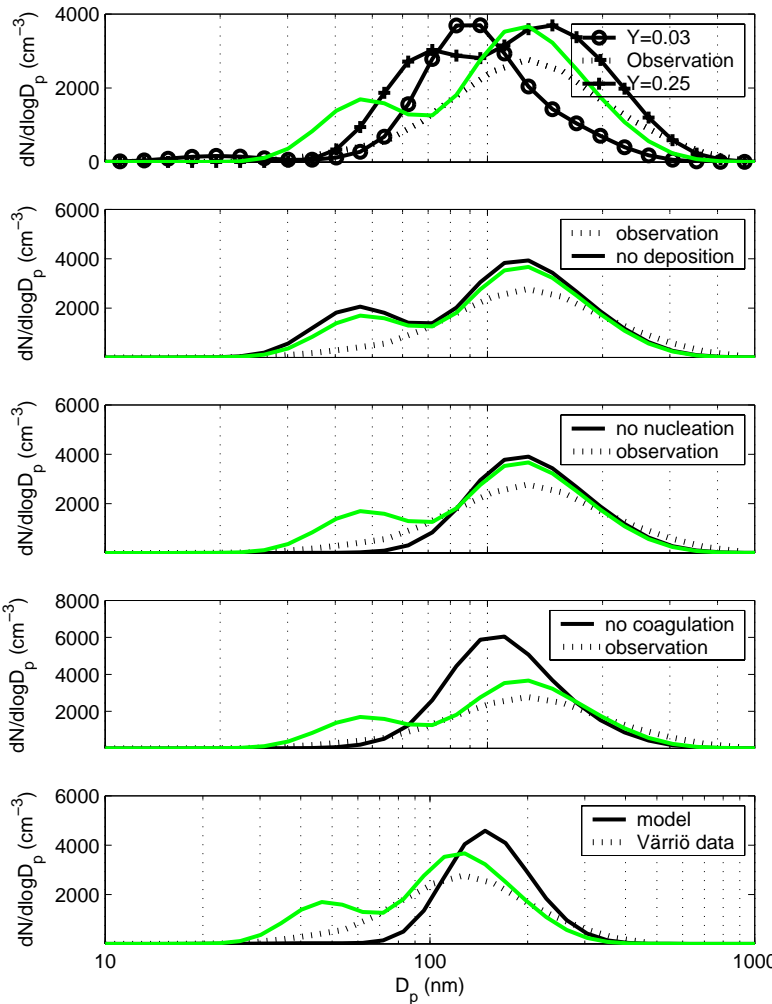

Fig. 9. Summary of results from the six different case studies. Dashed lines indicate observed data and solid line number size distribution as predicted by the model. Green line indicates size distribution derived from simulations under base case conditions.

4, 7757-7794, 2004

A pseudo-Lagrangian model study of the size distribution properties over Scandinavia

P. Tunved et al.

Title Page

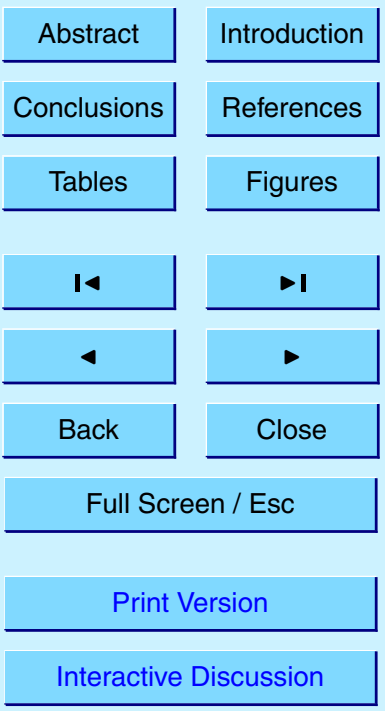

